Historic, Archive Document

Do not assume content reflects current scientific knowledge, policies, or practices. 



\section{$\sum 10$}

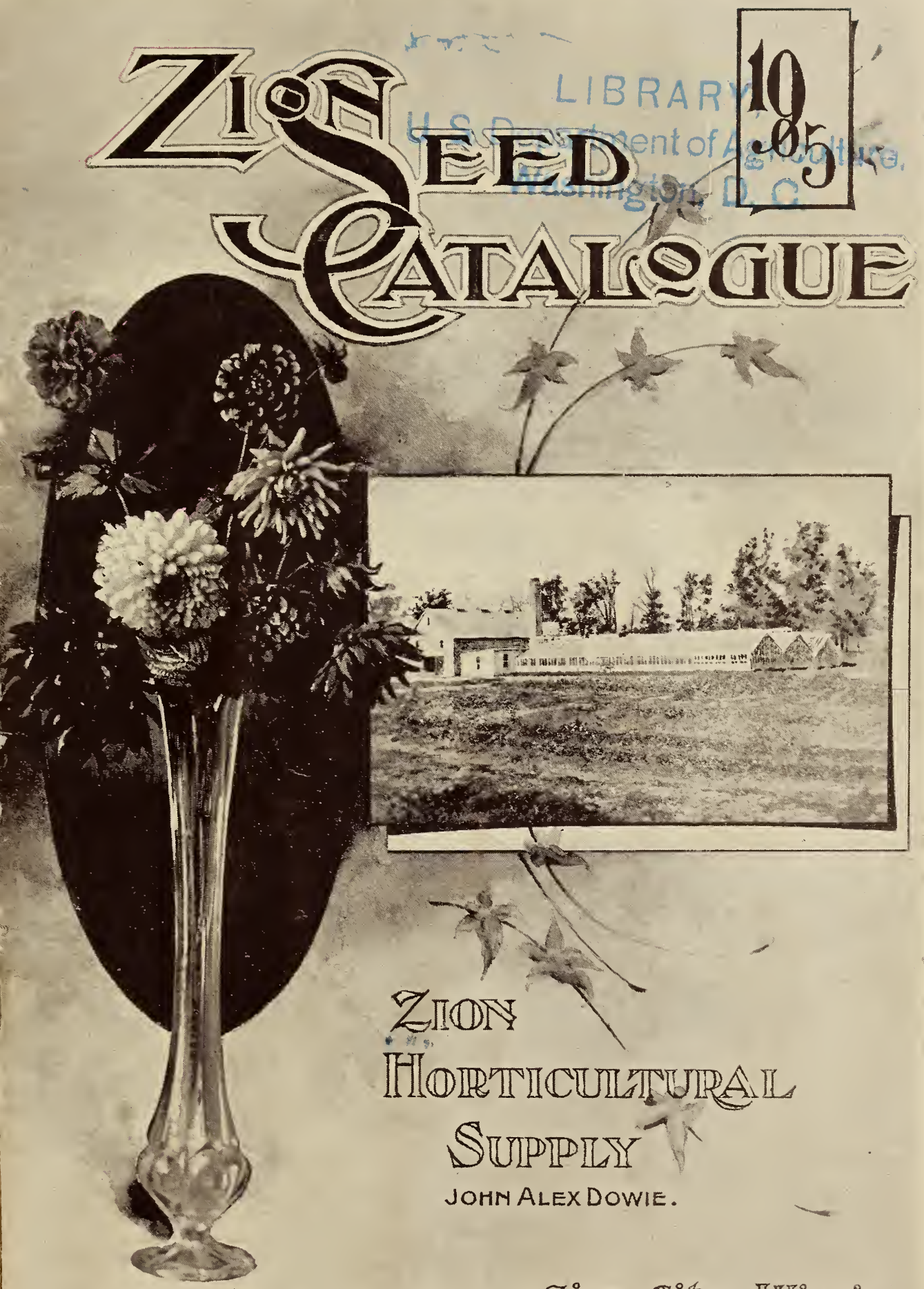

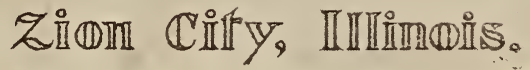




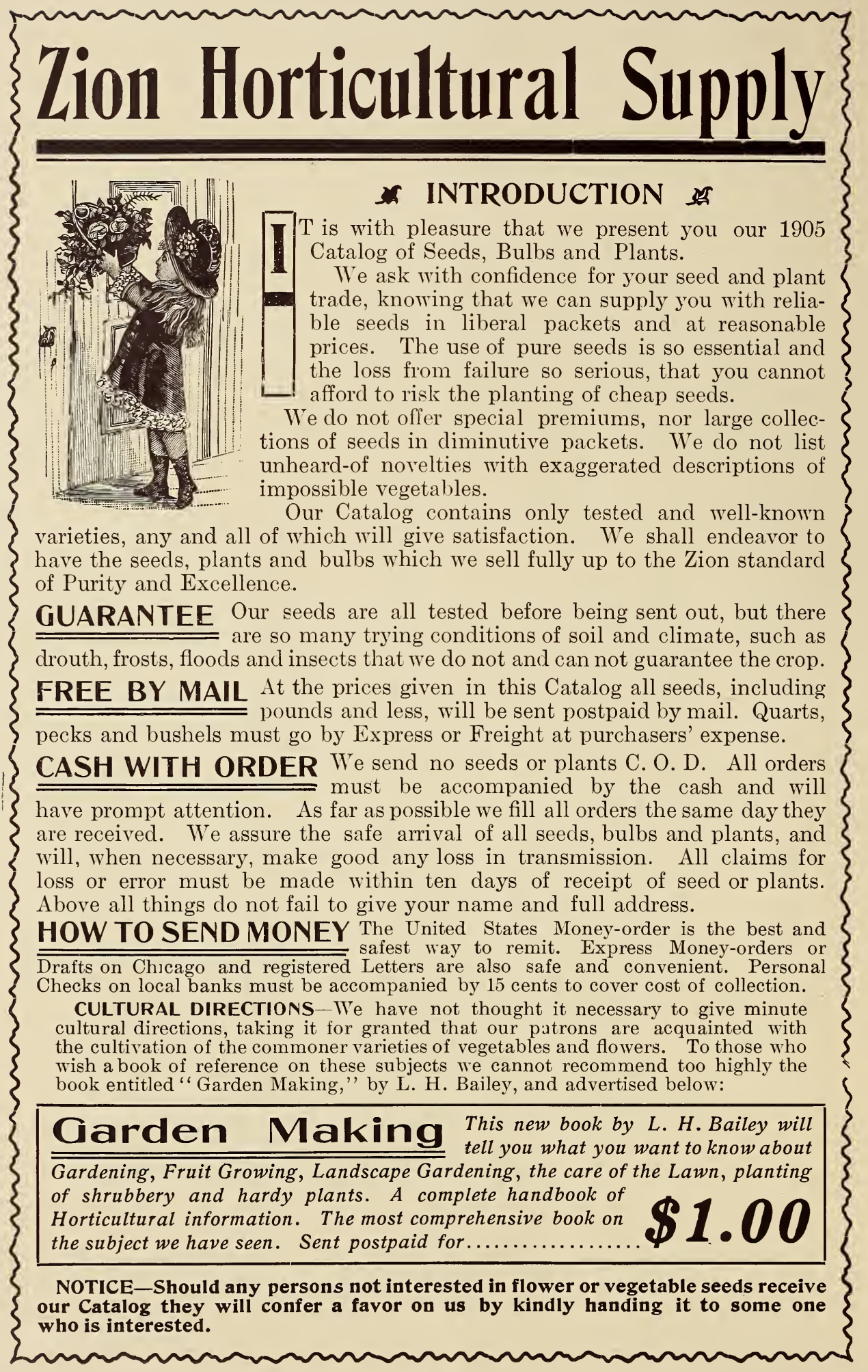




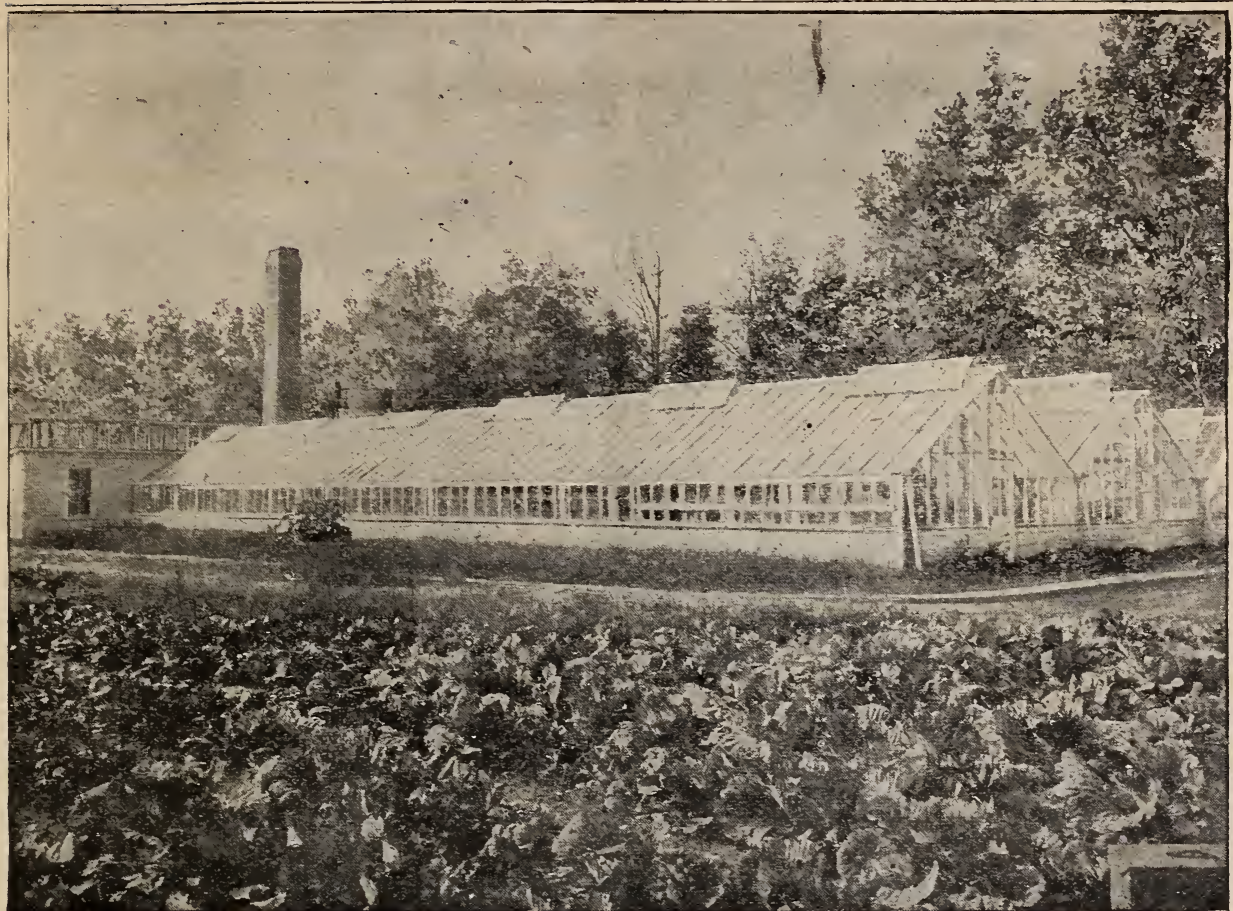

\section{GENERAL LIST OF VEGETABLE SEEDS}

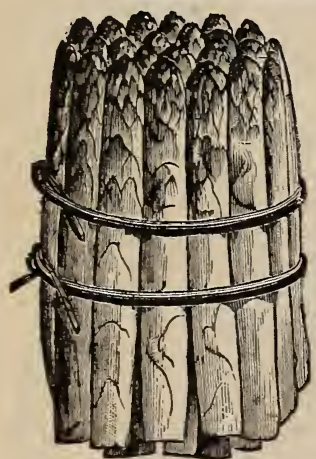

\section{ASPARAGUS}

The Asparagus bed furnishes the first green delicacy for our table in the spring and requires but little care for its successful cultivation. The seed should be sown in March or April, just as soon as the ground can be worked, in good, rich, mellow soil, in drills one foot apart, then cover with earth from one-half to three-quarters inches deep. Conovers Colossal. The Standard Variety. Price of Seeds, per pkt. 5, oz. 10c, $1 / 4 \mathrm{lb}$. 20c, lb. 50c. ROOTS. One=year=old roots, $100,60 \mathrm{c}, 1000$, \$5.00; two =year=old roots, $100,80 \mathrm{c}, 1000$, $\$ 6.00$. If sent by mail add 25c. per hundred for one=year=olds and $50 c$. per 100 for two=year=olds.

\section{BRUSSELS SPROUTS}

heads, or knobs along the stems bage. Sowing in the month of Jine will produce a late Autumn crop of sprouts which may be wintered under corn fodder or other coarse litter. Break the leaves off the stem and the heads will improve in growth. Should be treated in all respects as winter cabbage.

Paris Market Finely formed heads, solid round, growing closely on the stalks. Lb. $\$ 3.00,1 / 4 \mathrm{lb}$. 80c, oz. $30 \mathrm{c}$, pkt. $5 \mathrm{c}$.

\section{BORECOLE OR KALE}

Dwarf Green Curled This is hardier than cabbage, anc and Spring use. Sow seed in May or June, transplant in July and treat same as cabbage. Lb. $60 \mathrm{c}, 1 / 4 \mathrm{lb} .20 \mathrm{c}$, oz. $10 \mathrm{c}$, pkt. $5 \mathrm{c}$.

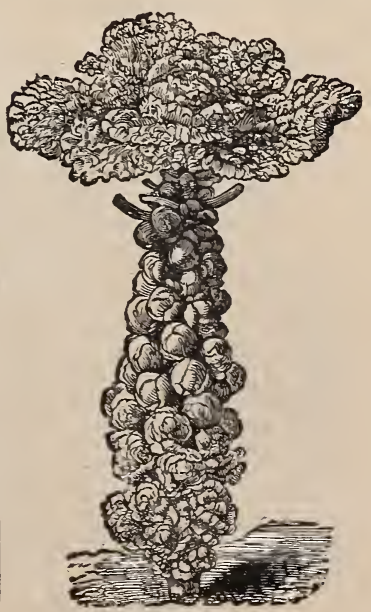




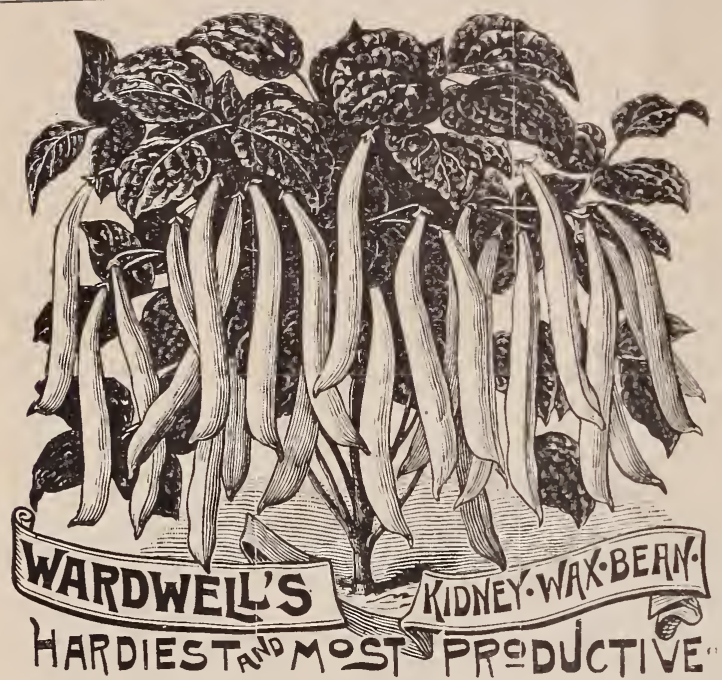

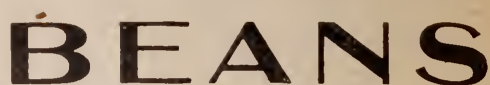

Improved Earliest

Valentine The earliest greended variety, with por the finest quality in ripening. One of the most profitable sorts for the gardener.

\section{Mammoth Stringless}

Green Pod A mammoth podthe green pod, not quite so early but larger and more showy and fine in quality.

\section{Extra Early Refugee $\begin{gathered}\text { A } n \text { - } \\ \text { other }\end{gathered}$} early green-podded sort of finest quality and great productiveness, by some said to be the earliest of ail.

Early Mohawk Quite early and very hardy, large, flat, dark green pods, five to six not remain in good condition as long as some others.

Davis Wax One of the best yellow-podded sorts for market-gardeners and canners' Wardwell's Kidney Wax An excellent Wax Bean, bearing long, flat pods of a hardy and robust in growth than most wax beans.

Currie's Rust-Proof Wax This variety is claimed, as its name indicates, to be hardy, and an early and abundant bearer.

Golden Wax A good early Wax Bean well known to all.

Burpee's Bush Lima The true bush form of large pole Lima Bean. It grows to Burpee's Busht of 18 to 20 inches, forming a circular bush, requiring no poles or stakes, yielding from 50 to 150 fine pods similar in size and quality to those grown on the large white Lima bean.

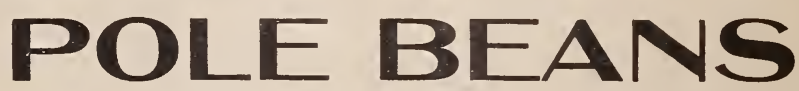

Old Homestead, or Kentucky Wonder Produces pods in clusters ready for Horticultural, or Speckled Cranberry A good snap short, matures early; King of the Garden Lima A vigorous grower, bearing profusely; large pods, and of rich flavor. from 5 to 8 inches in length. The beans are large

These prices, except for packets, do NOT include postage. If wanted by mail add 8 cents to the pint and 15 cents to the quart prices.

\begin{tabular}{|c|c|c|c|c|c|c|}
\hline Improved Earliest Valentine.... & $\begin{array}{r}\text { Pkt. } \\
. \$ 0: 10\end{array}$ & $\begin{array}{c}\text { Pt. } \\
\$ 0.15\end{array}$ & $\begin{array}{c}\text { Qt. } \\
\$ 0.25\end{array}$ & $\begin{array}{l}1 / 2 \mathrm{Pk} . \\
\$ 0.75\end{array}$ & $\begin{array}{l}\text { Pk. } \\
\$ 1.25\end{array}$ & $\begin{array}{c}\text { Bu. } \\
\$ 4.75\end{array}$ \\
\hline Mammoth Stringless Green Pod . & .10 & .15 & .25 & & & \\
\hline Extra Early Refugee .............. & .10 & .15 & .25 & .75 & 1.25 & 4.75 \\
\hline Early Mohawk............ & .10 & .15 & .25 & .75 & 1.25 & 4.75 \\
\hline Davis Wax.................. & .10 & .20 & .35 & & & \\
\hline Wardwell's Kidney Wax & .10 & .20 & .35 & & & \\
\hline Currie's Rust-Proof Wax. & .10 & .20 & .35 & 1.10 & & \\
\hline Golden Wax .............. & .10 & .20 & .35 & 1.10 & 2.00 & 7.00 \\
\hline sh, or Broad Windsor & .10 & .20 & .35 & 1.10 & 2.00 & \\
\hline ee's Bush Lima....... & .10 & .15 & .30 & 1.00 & 1.85 & 7.00 \\
\hline Kentucky Wonder-Pole & .10 & .15 & 3 & 1.10 & & 6.75 \\
\hline Horticultural Cranberr & .10 & .15 & .30 & .90 & 1.50 & 5.75 \\
\hline King of the Garden Lima- & 10 & & .30 & 1.00 & 1.75 & 6.50 \\
\hline
\end{tabular}

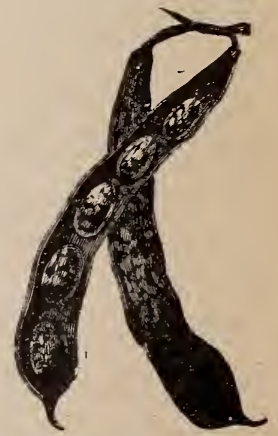

Yellow podded Beans were a short crop and we cannot guarantee prices on bushel lots. 


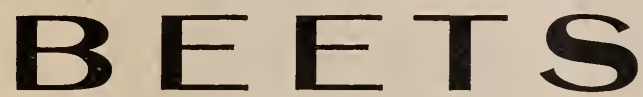

Crosby's Egyptian A selection from the early as the Egyptian and with added thickness, giving it a more desirable shape. It is the deepest red, almost black in color, and of the finest quality. The very best sort for early market as it makes beets of marketable size sooner than any other variety. Lb. $60 \mathrm{c}, 1 / 4$ lb. $25 \mathrm{c}$, oz. $10 \mathrm{c}$, pkt. $5 \mathrm{c}$.

Eclipse Roots nearly globular, with small tap root and no side roots, bright red color. Many gardeners grow this variety in preference to the Egyptian. Lb. 60c, $1 / 4$ lb 25c, oz. 10c, pkt. כ́c.

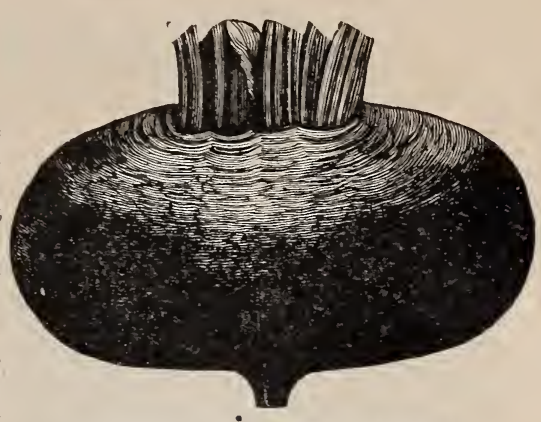

Egyptian Blood Turnip Beet

Dewing's Early Blood Turnip An improved variety of the Early Blood Turnip Beet, of deep blood red color, fine form and flavor; an excellent market sort. Lb. 55c, 1/4 lb. $25 \mathrm{c}$, oz. $10 \mathrm{c}, \mathrm{pkt}$. $5 \mathrm{c}$.

Crimson Globe This is a second early sort, remarkable for its smooth skin and fine shape; has many desirable qualities, does not grow large and coarse, the mature beets being medium in size and rather oblong in shape. The flesh and skin are both very dark and quality fine. This beet is sure to please. Lb. $75 \mathrm{c}, 1 / 4 \mathrm{lb} .25 \mathrm{c}, \mathrm{oz} .10 \mathrm{c}, \mathrm{pkt}$. $5 \mathrm{c}$.

\section{$B E E T$ - MANGELS} Mammoth Long Red This variety is enormously productive, yielding from 50 to lbs. Of great value for stock feeding. Lb. 40c, oz. 5c, $10 \mathrm{lbs}$. $\$ 3.00$.

Golden Tankard The best Yellow Mangel in cultivation. Being very sweet it is much relished by milch cows and sheep. In shape it is almost cylindrical. Lb. 40c, oz. 5c, 10 lbs. by express at purchaser's expense, $\$ 3.00$.

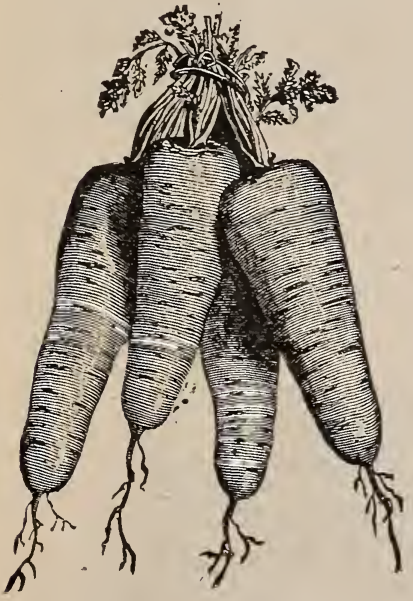

\section{CAULIFLOWER}

Early Snowball

ery early, and one of the surest to make fine large heads. If planted March 1st, large sized heads will be produced early in June. This is the standard early variety and is listed under many names. We see no need of offering many varieties which do not differ one from the other. Per oz. $\$ 2.50$, pkt. $10 \mathrm{c}$ and $20 \mathrm{c}$.

Lenormand's Short Stem A large, late, short-stemmed variety, with well-formed heads of extra quality. Per oz. $\$ 1.00$, pkt. $10 \mathrm{c}$.

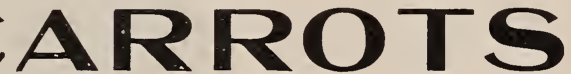
stump - rooted variety, and the sweetest of all carrots. The roots form a perfect and without a core. Lb. $80 \mathrm{c}, 1 / 4$ lb. $25 \mathrm{c}$, oz. 10c, pkt. $5 \mathrm{c}$ variety is a very heavy crop-
$4 \mathrm{lb} .25 \mathrm{c}, \mathrm{oz} .10 \mathrm{c}$, pkt. $5 \mathrm{c}$.

Danvers A rich orange-red variety, very smooth and handsome, producing large crops. The roots blunt point, flesh sweet, crisp and tender. taper to a blunt point, flesh
Lb. $85,1 / 4$ lb. $25 \mathrm{c}$, oz. $10 \mathrm{c}$, pkt. $5 \mathrm{c}$.

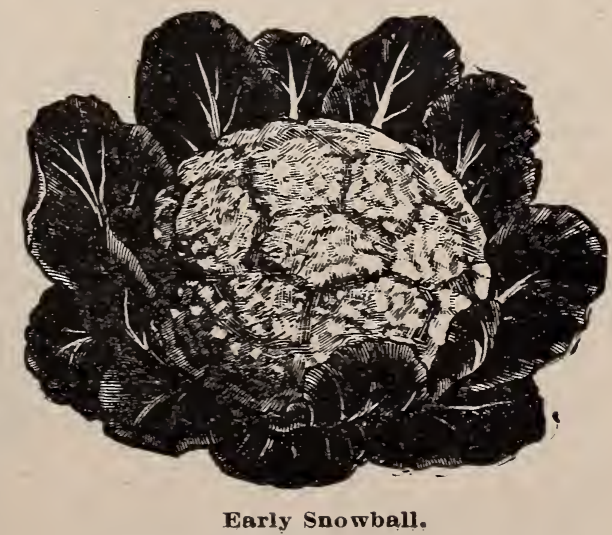




\section{CABBAGE}

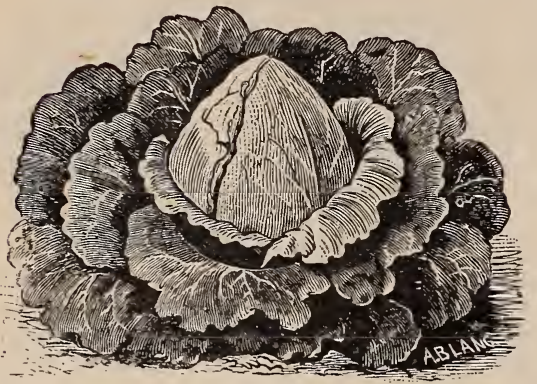

Early Jersey Wakefield

Early Jersey Wakefield This is unquestionably the leading early cabbage in America. The heads are of good size, conical in shape, with few outoutside leaves, and of excellent quality. Lb. $\$ 3.00,1 / 4$ lb. $80 \mathrm{c}$, oz. $30 \mathrm{c}$, pkt. $5 \mathrm{c}$.

Early Spring An early flat headed variety, heads often weigh 5 lbs. each and as Wakefield; form in size and shape. Adapted to family garden or market. Lb. $\$ 2.50,1 / 4 \mathrm{lb} .65 \mathrm{c}, \mathrm{oz} .25 \mathrm{c}$, pkt. 5c.

All Head Early The name describes the all head, coming in soon after the earliest varieties and good also for later planting. Lb. $\$ 2.50,1 / 4 \mathrm{lb}$. $65 \mathrm{c}, \mathrm{oz} .25 \mathrm{c}, \mathrm{pkt} .5 \mathrm{c}$.

Fottler's Improved Brunswick A fine summer or fall variety, with large flat header. Lb. $\$ 2.00,1 / 4$ lb. $60 \mathrm{c}, 0 \mathrm{z} .20 \mathrm{c}$, pkt. 5c.

Dutch Winter or Hollander The best cabbage for storing during winter, and ate spring sales. The heads are of medium size, averaging about $8 \mathrm{lbs}$, very solid and round as a ball, causing them to show up well when
trimmed. Lb. $\$ 3.00,1 / 4 \mathrm{lb}$. $80 \mathrm{c}$, oz. 30c, pkt. $5 \mathrm{c}$.

\section{Marvin's Sa voy Cabbage This variety and solid, with curly leaf. Much sweeter than other cabbages, resembling the Cauliflower in flavor. Lb. $\$ 2.25,1 / 4$ lb. $60 \mathrm{c}$, oz. 20 , pkt. $5 \mathrm{c}$.}

\section{Mammoth Rock Red}

A very large, sure heading red cabbage, deep red to the center, in every way a first

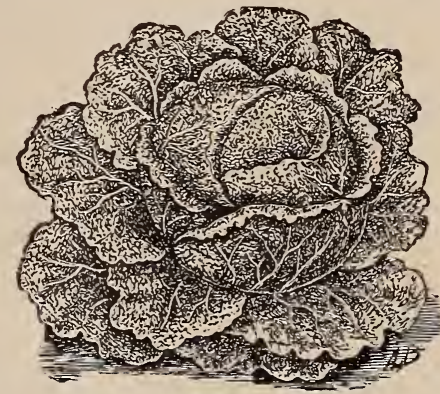

Premium Flat Dutch This splendid more largely grown than any other sort, until the advent of the Dutch Winter or Hollander. It forms very large solid heads of fine quality, unsurpassed for market. Lb. $\$ 2.00,1 / 4 \mathrm{lb}$. $60 \mathrm{c}$, oz. $20 \mathrm{c}$, pkt. $5 \mathrm{c}$.
Marvin's Savoy Cabbage

class sort. Lb. $\$ 2.25,1 / 4$ lb. $65 \mathrm{c}$, oz. $25 \mathrm{c}$, pkt. $5 \mathrm{c}$.

White Plume This is the earliest and White Plume most easily blanched, but not quite so good a keeper as some other varieties. The plants grow rapidly and blanch easily during the summer months. Later in the fall the central stalks and leaves are of pure snowy whiteness, even without earthing up, but the stalks should be gathered together and earthed up as in other varieties to produce the best results. Lb. $\$ 2.00,1 / 4 \mathrm{lb} .60 \mathrm{c}, \mathrm{oz} .20 \mathrm{c}$, pkt. $5 \mathrm{c}$. Golden Self-Blanching ${ }_{\text {Celery }}$ for general use, some place it at the head of the list. Perfectly solid, crisp, brittle, and of delicious flavor, surpassed by no other variety. Also self-blanching to a remarkable degree, the heart is solid, and of a beautiful rich, golden yellow color. Lb. $\$ 3.25,1 / 4 \mathrm{lb}$. 90c, oz. $40 \mathrm{c}$, pkt. $10 \mathrm{c}$ and $5 \mathrm{c}$.

Dwarf Golden Heart A distinct sturdy dwarf habit; good to store in winter. Lb. $\$ 1.60,1 / 4 \mathrm{lb} .40 \mathrm{c}$, oz. $20 \mathrm{c}$, pkt. $5 \mathrm{c}$.

Giant Pascal One of the best for fall stalks are very large, thick, solid, crisp, and of a rich nutty flavor. A good shipper. Lb. $\$ 1.75,1 / 4$

Turnip Rooted In this variety the developed, the edible part being the large fleshy root or bulb, which is much used in soups, Lb. $\$ 2.00,1 / 4 \mathrm{lb}, 60 \mathrm{c}, 0 \mathrm{z}, 20 \mathrm{c}$, pkt $5 \mathrm{c}$,

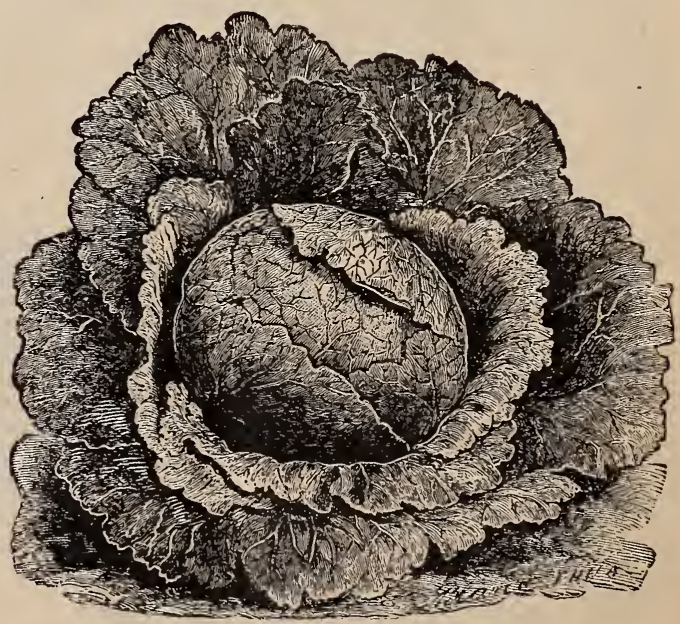

Holland Hard Heading 


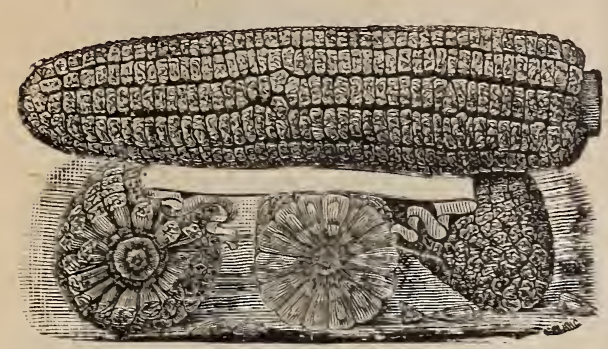

\section{SWEET CORN}

Peep-0'-Day Earliest corn on earth, Cory, which has heretofore been considered the earliest. Peck $\$ 1.50$, qt. $25 \mathrm{c}$, pint $15 \mathrm{c}$, pkt. $10 \mathrm{c}$.

Mammoth White Cory The standearly variety, has pure white cob and is very prolific. Probably more of this variety is planted than of any other early corn. A moneymaker for the early market. Peck $\$ 1.50$, qt. $25 \mathrm{c}$, pint $15 \mathrm{c}$, pkt. $10 \mathrm{c}$.

Early Champion We are naming varieties in the order of their ripening, and while extra fine quality. A splendid sort for market. Peck $\$ 1.50$, qt. 25c, pint 15c, pkt. 10c.

Early Evergreen Ripens ten days earlier than Stowell's Evergreen, and equally as good quality. Peck $\$ 1.50$, qt. $25 \mathrm{c}$, pint $16 \mathrm{c}$, pkt. 10c.

Country Gentleman The standard for excellence, ripens about the same as Stowrows and deliciously sweet. Usually arerages three ears to the stalk. Peck $\$ 2.00$, qt. 30c, pint 15c, pkt. 10c.

Stowell's Fvergreen The best for main crop, as it is not only tender and sugary, too hard. Peck $\$ 1.75,1 / 2$ peck $\$ 1.00$, qt. $30 \mathrm{c}$, pint $20 \mathrm{c}$, pkt. $10 \mathrm{c}$.

\section{CUCUMBERS}

White Spine The fruit is long, straight and round, with a rich period of its growth, good either for forcing or growing in the open ground. Lb. $\$ 2.00,1 / 4 \mathrm{lb} .60 \mathrm{c}, \mathrm{oz} .25 \mathrm{c}, \mathrm{pkt}$. $5 \mathrm{c}$.

Improved Long Green The leading variety of Long Green orous and productive, grood either pickles when allowed to ripen. Lb. $\$ 200,1 / 4 \mathrm{lb}$. $60 \mathrm{c}, \mathrm{oz} .25 \mathrm{c}, \mathrm{pkt}$. $5 \mathrm{c}$. Extra Early Green Prolific An early pickling sort, enorwith pickle growers and gardeners. $\mathrm{Lb}$ mously productive, a favorite pkt. כै.

\section{Improved Chicago Pickle The fruit is of medium length,} and prominent spines, color deep green, vines begin to set fruit when quite young. Lb. $\$ 2.00,1 / 4$ lb. 60c, oz. $25 \mathrm{c}$, pkt. $\mathrm{c}$.

Early Frame An early short green variety. Lb. $\$ 2.00,1 / 4 \mathrm{lb} .60 \mathrm{c}$, oz. 25c, pkt. 5́c.

Snow Pickling This selection made by a veteran western pickle grower, ranks at the thing choice should order this variety. Lb. $\$ 2.00,1 / 4 \mathrm{lb} .60, \mathrm{oz} .25 \mathrm{c}$, pkt. $5 \mathrm{c}$.

Rollison's Telegraph This is an English variety for growing in the greenhouse. Grows to specimens can also be grown in hotbeds or even in the open ground. Pkt. of ten seeds 10c.

\section{CHICORY}

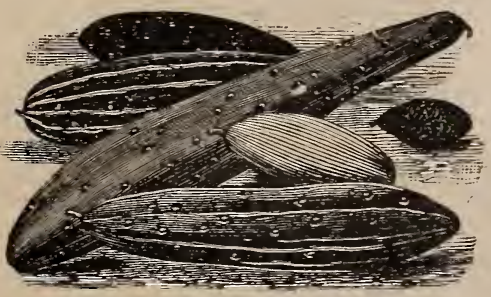
Large Rooted The leares are used as salads with state or blanched. The roots are used as a substitute for coffee or to adulterate the same. Lb. $60 \mathrm{c}, 1 / 4 \mathrm{lb}, 20 \mathrm{c}, \mathrm{oz} .10 \mathrm{c}$, pkt. $5 \mathrm{c}$.

CRESS
Curled Garden Much used with lettuce, to which it $50 \mathrm{c}, 1 / 4 \mathrm{lb} .15 \mathrm{c}$. oz. $5 \mathrm{c}$.

\section{CORN SALAD}

Round Leaved A most refreshing salad; used in winter and spring as a substitute for lettuce, also cooked like spinach. Lb. $60 \mathrm{c}, 1 / 4 \mathrm{lb} .20 \mathrm{c}, \mathrm{oz} .10 \mathrm{c}$, pkt. $5 \mathrm{c}$. 


\section{EGG PLANT}

\section{New York Improved Spineless}

Very large, fine dark color. We believe this to be the smooth and of so we offer no other. Lb. $\$ 4.00,1 / 4$ lb. $\$ 1.25$, oz. 35c, pkt. 5c.

\section{ENDIVE}

A plant resembling lettuce, but with a somewhat bitter taste like the Dandelion, much used for the fall and winter months. Heads should be tied together in order to blanch the center. Green Curled Winter In this variety the leaves are it a mossy finely cut and curled, giving it a mossy appearance. Lb. $\$ 1.25,1 / 4 \mathrm{lb} .40 \mathrm{c}$, oz. $15 \mathrm{c}$, pkt. $5 \mathrm{c}$. White Curled This variety does not need blanching to $15 \mathrm{t}$, pkt. $5 \mathrm{c}$.

\section{KOHL RABI}

This vegetable partakes of the nature of both the Turnip and the Cabbage; it might be called a turnip growing above ground on a stem. It is very quick-growing and very tender and sweet when young; does not become wormy as turnips often do.

Early White Vienna Flesh white tender; leaves short. Lb. $\$ 2.20,1 / 4 \mathrm{lb} .60 \mathrm{c}$, oz. 30c, pkt. 5c.

\section{LEEK}

A vegetable somewhat resembling an onion, but does not form so large a bulb, will remain in the ground all winter, sow the seed in spring and transplant in rows 1 foot apart, with plants 4 inches apart in the row.

\section{Large}

Musselburg Enorsize; leaves large and broad; mild pleasant flavor. lb. 30c, oz. 10c. pkt. 5c.

\section{MUSTARD}

White London Mostly grown for its seeds which are much used in pickles, Chili sauce, etc. Lb. $40 \mathrm{c}, 1 / 4$ lb. $15 \mathrm{c}$, oz. $10 \mathrm{c}$, pkt. 5c.

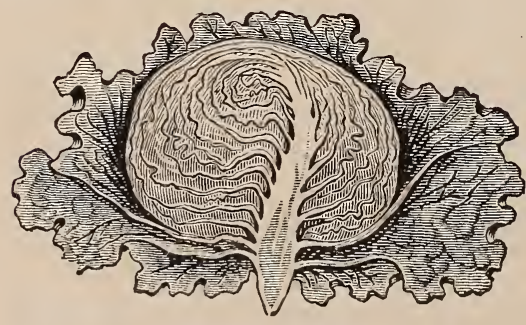

Hanson Lettuce.

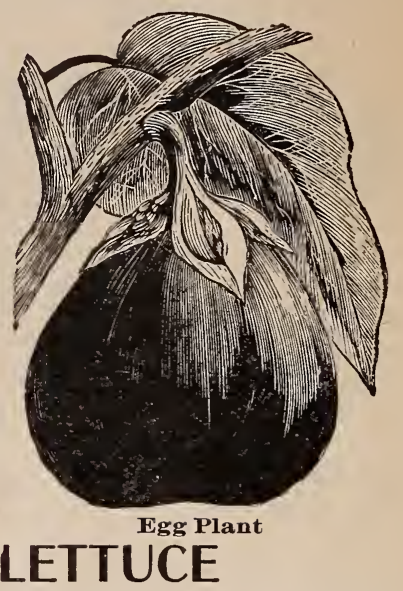

In demand every month in the year, grown in greenhouses, hot-beds, cold frames and in the open ground.

Grand Rapids Forcing This fine especially valuable for bed culture, it does not form a solid head, but makes large compact bunches of finely curled leaves of the finest quality. One of the very best for winter growing. Lb. $\$ 1.25$, $1 / 4$ lb. $40 \mathrm{c}$, oz. $15 \mathrm{c}$, pkt. $5 \mathrm{c}$.

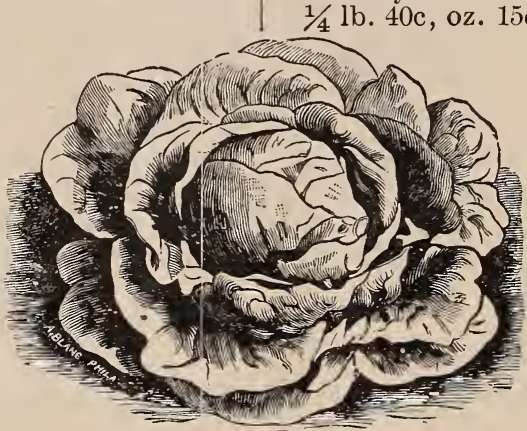

8t. Louis Butter Head.

\section{Black Seeded}

Simpson One of the non-heading sorts, simila r to Grand Rapids Forcing. Outside leaves a re a light yellowish green, the inner ieaves being blanched a $1 \mathrm{~m}$ os t white. Resists the heat and is slow in running to seed. Lb. $\$ 1.25,1 / 4 \mathrm{lb}$. $40 \mathrm{c}$, oz. $15 \mathrm{c}$, pkt. $5 \mathrm{c}$.

Big Boston $\begin{gathered}\text { A fine } \\ \text { variety }\end{gathered}$ Lb. $\$ 1.10,1 / 4$ for cold frames during the Winter months; forms large heads often 12 inches across; will grow in a colder temperature than most varieties. Is grown largely in the South for shipping to northern markets, sure to please those who want something immense in size. Lb. $\$ 1.25,1 / 4 \mathrm{lb} .40 \mathrm{c}, \mathrm{oz}$. $15 \mathrm{c}$, pkt. $5 \mathrm{c}$.

St. Louis Butter Head $\underset{\text { favorite }}{\mathrm{A}}$ with gardners for outdoor growing, as it forms solid heads of finest flavor, buttery and crisp, standing the heat well and slow in running to seed. Lb. $\$ 1.25,1 / 4 \mathrm{lb}$. $40 \mathrm{c}$, oz. $15 \mathrm{c}$, pkt. $5 \mathrm{c}$.

Improved Hanson This variety cabbage more than any other lettuce. Heads can be grown in the open ground which will weight 2 pounds, and when cut through the heart looks very much like a cabbage head. Heads green outside and white within. Lb. $\$ 1.25,1 / 4$ lb. $40 \mathrm{c}$, oz. $15 \mathrm{c}$, pkt. 5c. 


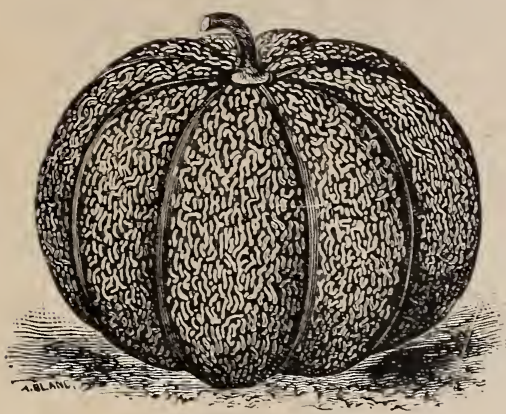

Montreal Market

\section{Muskmelon}

Paul Rose This new sort is a cross between coming the sweetness of the Osage with the fine gray netting and handsome appearance of the Netted Gem. It has given good satisfaction both for the market and home garden; orange flesh. Lb. $\$ 1.10$, $1 / 4$ lb. $40 \mathrm{c}$, oz. $15 \mathrm{c}$, pkt. 5c.

\section{Chicago Market Nutmeg This is one of} of the nutmeg varieties, very early to mature, large and uniform in size, skin thickly netted, seed cavity small, flesh deep green in color, juicy and delicious

in flavor; a favorite with all who prefer a green flesh sort. Lb. $90 \mathrm{c}, 1 / 4 \mathrm{lb} .30 \mathrm{c}, \mathrm{oz}$. $15 \mathrm{c}$, pkt. 5c.

Rocky Ford or Netted Gem This melon has probably made more stir among selection from the Netted Gem and takes its name from Rocky Ford, Colorado, from which place immense quantities have been shipped to all parts of the country. It is a small or basket melon, of oval shape, slightly ribbed and densely covered with fine netting; flesh thick, green and very sweet. Lb. $\$ 1.25,1 / 4 \mathrm{lb}$. $40 \mathrm{c}$, oz. $20 \mathrm{c}$, pkt. $5 \mathrm{c}$.

\section{Emerald Gem}

A splendid variety, fruit small to medium in size, slightly flattened at the ends, only slightly netted and ribbed; skin deep green while young, becoming tinged with vellow as the fruit matures; flesh deep salmon yellow, ripening close to the rind and exceedingly high flavored, especially suited to the hom e garden. Lb. $\$ 1.40,1 / 4 \mathrm{lb} .60 \mathrm{c}, \mathrm{oz}$. $20 \mathrm{c}$, pkt. 5c.

Montreal Market Nutmeg $\begin{aligned} & \text { Fruit of the largest size, often attaining a weight of } \\ & 15 \text { to } 20 \text { pounds; shape nearly round, flattened at the }\end{aligned}$ ends, deeply ribbed; flesh remarkably thick, green, lucious and of the finesi flavor. Lb. $\$ 1.50,1 / 4 \mathrm{lb}$. $45 \mathrm{c}, \mathrm{oz} .15 \mathrm{c}, \mathrm{pkt}$. $5 \mathrm{c}$.

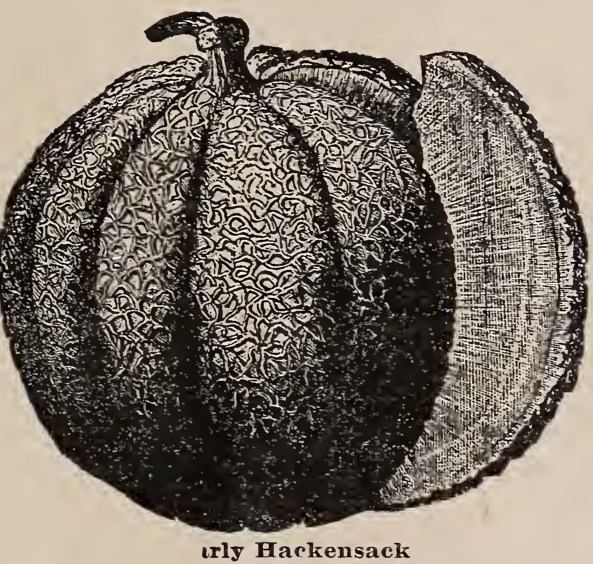

Extra Early Hackensack

This is a selection of the popular Hackensack, ripening fully ten days earlier, melons are of good size, deeply ribbed and coarsely netted; thick light green flesh of most delicious flavor. Lb. $\$ 1.15,1 / 4$ ib. $40 \mathrm{c}$, oz. $15 \mathrm{c}$, pkt. $5 \mathrm{c}$.

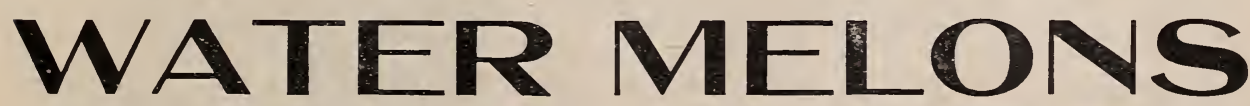

Black Diamond A cross between Kolb's Gem and shipper than Kolb's Gem, and just as good quality as Sweetheart, but excells both these splendid rarieties in size and productiveness. This melon grows to an immense size and is said to be the most prolific melon ever planted. Its color is rich dark green, almost black; shape roundish to blunt oval and rery uniform. Lb. $75 \mathrm{c}, 1 / 4 \mathrm{lb}$. $25 \mathrm{c}$, oz. $10 \mathrm{c}$, pkt. $5 \mathrm{c}$.

Coles' Earlý Melons are oval in form, small in size, Fandsomely striped with light and dark ess and delicious texture of flesh it has no superior, very desirable to grow for home use, extremely early. Lb. $70 \mathrm{c}, 1 / 4 \mathrm{lb} .25 \mathrm{c}, 0 \mathrm{z} .10 \mathrm{c}$, pkt. $5 \mathrm{c}$.

Early Fordhook Extremely early, the form is nearly toug round, medium in size. The rind is medium green without stripes, seeds white. Lb. $75 \mathrm{c}, 1 / 4 \mathrm{lb}$. $25 \mathrm{c}$ medium green
oz. $10 \mathrm{c}$, pkt. $5 \mathrm{c}$.

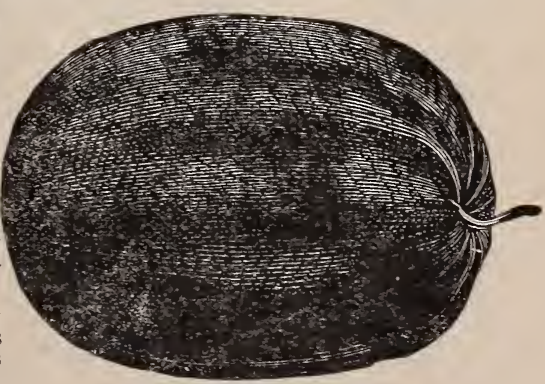

Black Diamond 


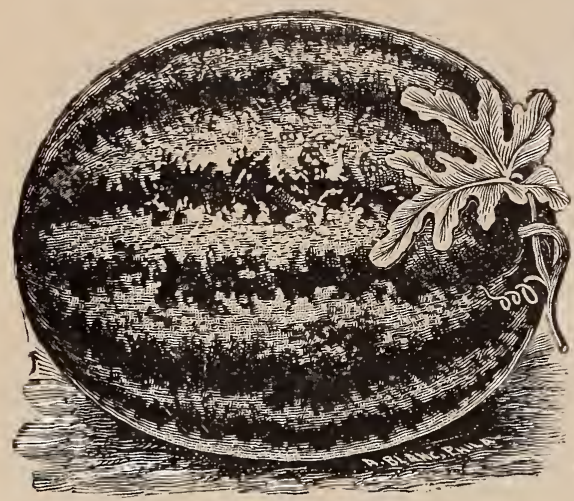

Kolb's Germ.
WATERMELONS

(CONTINUED.)

Kleckley's Sweet This new variety is one of the finest melons grown. The fruits are oblong 18 to 20 inches in length by 10 to 12 inches in diameter; flesh bright scarlet, sweet, sugary and melting, entirely without pulp or strings. The rind is only about onehalf an inch in thickness. The large solid heart does not crack open when ripe. Not the best melon for shipping, but it is certainly unsurpassed for the home garden, and the very best table melon grown. Lb. $80 \mathrm{c}, 1 / 4$ lb. $25 \mathrm{c}$, oz. $10 \mathrm{c}$, pkt. $5 \mathrm{c}$.

Kolb's Gem Largely grown in the South for shipping to the Northern markets; fruits of the largest size and blocky form, skin handsomely marked in dark and light green stripes. Not as fine flavor as Kleckley's but the best shipper in the list. Lb. $70 \mathrm{c}, 1 / 4$ lb. $25 \mathrm{c}$, oz. 10c, pkt. $5 \mathrm{c}$.

Sweetheart A most popular, new and distinct shipping variety, fruits large and heavy, nearly round; skin pale green mottled or netted with dark green; flesh solid, deep red, crisp and luscious. A good keeper, very productive and a good shipper. Lb. $70 \mathrm{c}, 1 / 4$ lb. 25c, oz. 10c, pkt. 5c.

Triumph A Southern variety which has become very popular with shippers. A cross between Duke Jones' and Kolb's Gem; of handsome appearance and a good shipper. Very early, productive, deliciously sweet and of immense size. An excellent melon. Lb. $70 \mathrm{c}, 1 / 4$ lb. $25 \mathrm{c}, \mathrm{oz} .10 \mathrm{c}$, pkt. $5 \mathrm{c}$.
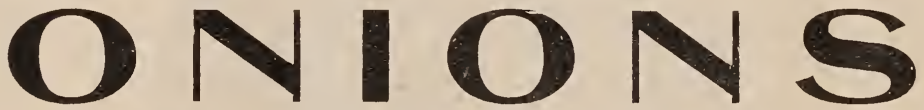

One of the most important garden crops and universally grown and used. The use of good seed of this vegetable is very essential, poor seed causing scullions or stiff necks, or poorly ripened bulbs which are difficult to keep. Our seed is thoroughly reliable.

Red Weathersfield The standard red variety, very productive and of the largest size; form somewhat flattened, skin a deep purplish red. The best variety for poor or dry soils. Lb. $\$ 1.10,1 / 4 \mathrm{lb} .35 \mathrm{c}$, oz. $15 \mathrm{c}$, pkt. 5c.

Southport Large Red Globe Aglobeonion of a beautiful crimson color, generally commands an extra price in market because of its beautiful shape and color. This variety is medium in size, globular in form with small neck. Fine for market and shipping, commanding an extra price in carload lots. Lb. $\$ 1.40,1 / 4$ lb. 50c, oz. $20 \mathrm{c}$, pkt. $5 \mathrm{c}$.

Prizetaker A handsome onion of the very largest size and perfect globular form, skin a bright straw color, the necks are small and the onions ripen up hard. Many gardeners sow this variety in hot-beds in March and later transplant to the open ground when plants are the size of slate pencils. By this method immense onions are produced even in the North. Lb. $\$ 1.40$, $1 / 4$ lb. 50c, oz. 20c, pkt. $5 \mathrm{c}$.

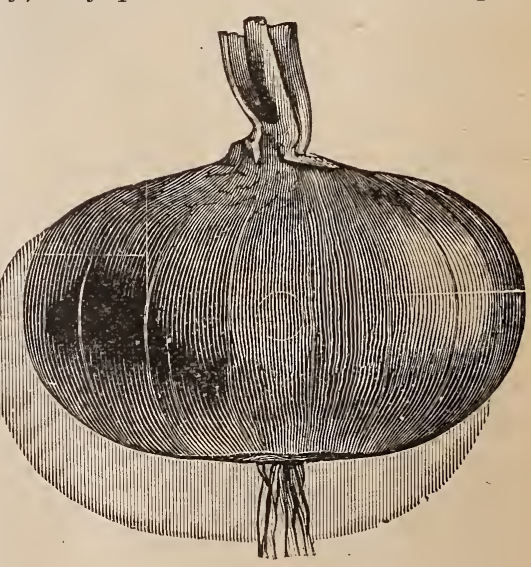

Red Weathersfield.

We believe that every Description in this Catalog is under rather than overdrawn. All worthless varieties are eliminated and only the best retained. See our Collections of Seeds and Plants on third Cover Page. 


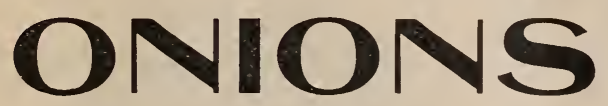

(CONTINUED.)

Yellow Globe Danvers

Too well known to need description. The main point is to have a good strain of seed, and that we can supply. Lb. $\$ 1.10$, 1/7 lb. $40 \mathrm{c}, \mathrm{oz} .15 \mathrm{c}$, pkt. 5c.

White Portugal, or Silverskin This vachiefly used for growing sets. The mature onions are large and flat, with a beautiful clear skin of silvery whiteness. A good market sort, also a favorite for pickles or for bunching when young. A good keeper, and taken in all a satisfactory sort. Lb. $\$ 1.65,1 / 4 \mathrm{lb}$. $60 \mathrm{c}$, oz. 20c, pkt. $5 \mathrm{c}$.

Southport White Globe A large, handsome, skin and flesh both pure white; the flesh is firm, finegrained and of mild flavor. Great care must be used

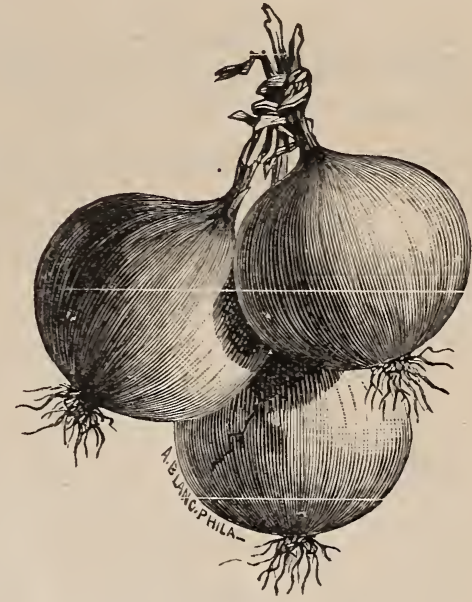

Yellow Globe Danvers. in harvesting this variety to keep them from rain or dew, as this is sure to discolor them. When well grown this sort brings an extra price in market. Lb. $\$ 2.00$, 1/4 lb. 65c, oz. 25c, pkt. 5c.

Australian Brown Quick to mature, a long keeper, solid and heavy, an excellent being but slightly flattened; reddish brown in color, and very hard; rather strong flavored. Lb. $\$ 1.25$, 1/4 lb. $50 \mathrm{c}, 0 \mathrm{z} .20 \mathrm{c}$, pkt. $5 \mathrm{c}$.

Mammoth Silverskin This mammoth white variety is one of the largest in cultivation, averaging from 5 to 7 inches when well grown. It grows quickly and matures early, and is of uniformly large size and fine shape, being flattened but thick. The thin skin is a clear silvery white. The flesh is snow-white, sweet and tender. Its striking size and handsome appearance, as well as mild flavor, recommend it for exhibition and for the fancy market as well as the table. Lb. $\$ 1.75,1 / 7 \mathrm{lb} .60 \mathrm{c}, \mathrm{oz} .20 \mathrm{c}$, pkt. $5 \mathrm{c}$.

White Adriatic Barletta This is an extra early, very small, round, hard and flavor mild and delicate. This onion is used in all the famous pickle factories in this country. Lb. $\$ 2.00,1 / 4$ lb. $60 \mathrm{c}$, oz. $20 \mathrm{c}$, pkt. $5 \mathrm{c}$.

New White Queen This variety resembles the Barletta in form and color. It is also New White Queen used for pickles, for early bunching, and for table use when mature. Lb. $\$ 2.00,1 / 4$ lb. $60 \mathrm{c}$, oz. $20 \mathrm{c}$, pkt. $5 \mathrm{c}$.

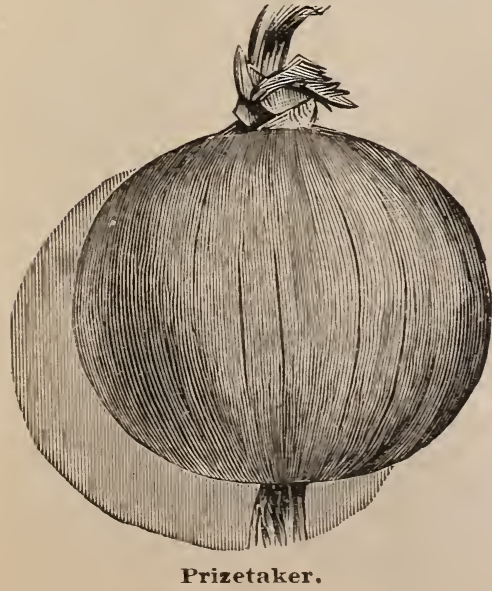

\section{CHOICE ONION SETS}

Prices subject to market change.

Postage on Onion Sets 10 cents per qt. additional.

Per qt. Per $1 / 2$ pk. Per pk. Per bu.

Yellow Onion Sets....... \$0.20 $\$ 0.60 \quad \$ 1.00 \$ 3.00$

$\begin{array}{llllll}\text { Red Onion Sets.......... } & .20 & .60 & 1.00 & 3.00\end{array}$

$\begin{array}{llllll}\text { White Onion Sets........ } & .25 & .65 & 1.15 & 3.50\end{array}$

$\begin{array}{lllll}\text { White Potato (multiplier). } & .25 & .75 & 1.25 & 4.00\end{array}$

$\begin{array}{llllll}\text { Yellow Potato Onions..... } & .25 & .65 & 1.20 & 3.75\end{array}$

$\begin{array}{lllll}\text { Egyptian or Peremnial Tree } & .25 & .65 & 1.10 & 3.50\end{array}$

Garlic, per lb. 25c; by mail 35c.

Chives (see Vegetable Plants). 


\section{PARSLEY}

Used for garnishing and seasoning soups, meats, etc. Sow the seed thickly as early in spring as the ground can be worked, thin to six inches. The seed is very slow to germinate, and should be soaked several hours in water before sowing.

Double Curled Fine, dwarf, crimped of a bright green color. Lb. $60 \mathrm{c}, 1 / 4 \mathrm{lb}, 20 \mathrm{c}$ oz. 10c, pkt 5c.

\section{Champion Moss Curled}

The leares extra dark green color, having the appear-

ance of a bunch of finely curled moss. Lb. 7 c c, $1 / 4 \mathrm{lb}$. 25c, oz. 10c, pkt. 5c.

Hamburg or Turnip Rooted In this variety the root resembles a parsnip, $75 \mathrm{c}, 1 / 4$ lb. 25c, oz. 10c, pkt. 5c.

\section{PEPPERS}

Improved Sweet Moun.

tain This is a most vigorous and productive variety. The young peppers are of a bright green color without any tinge of purple. When ripe they are of a rich red color. The fruit is very large, often six inches or more in length, by three or four in diameter, without wrinkles or corrugations, thus making it one of the finest varieties to stuff with cab-

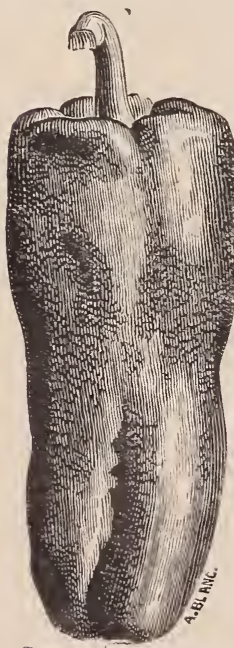

bage. The flesh is very thick, sweet and mild in flaror. Lb. $\$ 2.50, \quad 1 / 4 \quad \mathrm{lb}$. $65 \mathrm{c}, 0 \mathrm{z} .30 \mathrm{c}$, pkt. $5 \mathrm{c}$.

Large Bell or Bull Nose

This well known variety is perfectly reliable wich large fruit three inches in diameter by four in length. Bright scarlet when ripe. Lb. $\$ 2.00,1 / 4$ lb. $60 \mathrm{c}$, oz. $20 \mathrm{c}$, pkt. $5 \mathrm{c}$.

Cayenne Led the hariety which is used in Chili sauce or where something strong and pungent is desired. The fruit is slim and pointed, and when ripe is of a bright red color. Lb. $\$ 2.25,1 / 4$ lb. $70 \mathrm{c}$, oz. $15 \mathrm{c}$, pkt. $5 \mathrm{c}$.

Ruby King Another good variety of the largest size, also used for snooth and beautiful. Very bright scarlet; flesh mild and sweet. Lb. $\$ 2.2 .5,1 / 4$ lb. 70c, oz. $15 \mathrm{c}$, pkt. $5 \mathrm{c}$.

Celestial Jery strong, erect growth and very productive. The plant Celestial is covered with erect conical fruits about $1 \frac{1}{2}$ inches in length. The fruits when green are of a clear creamy tint, turning to scarlet when ripe. As these plants have both green and ripe fruit at the same time they are very attractive, and are sometimes grown in pots for Christmas

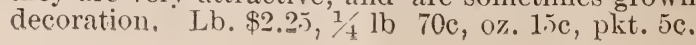



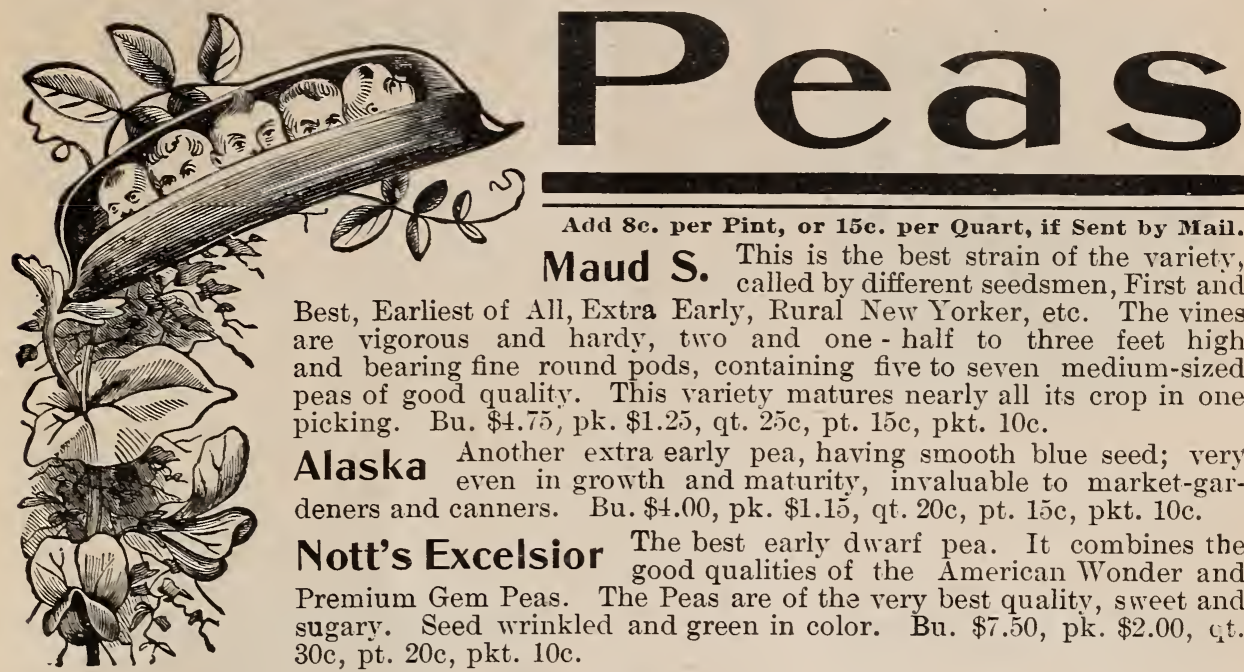

Add 8c. per Pint, or 15c. per Quart, if Sent by Mail.

Maud S. This is the best strain of the variety, Best, Earliest of All, Extra Early, Rural New Yorker, etc. The vine are vigorous and hardy, two and one - half to three feet high and bearing fine round pods, containing five to seven medium-sized peas of good quality. This variety matures nearly all its crop in one picking. Bu. $\$ 4.75$, pk. $\$ 1.25$, qt. $25 \mathrm{c}$, pt. $15 \mathrm{c}$, pkt. $10 \mathrm{c}$.

Alaska Another extra early pea, having smooth blue seed; very even in growth and maturity, invaluable to market-gardeners and canners. Bu. $\$ 4.00$, pk. $\$ 1.15$, qt. $20 \mathrm{c}$, pt. 1 jo, pkt. $10 \mathrm{c}$.

Nott's Excelsior The best early dwarf pea. It combines the Nott's Excelsior good qualities of the American Wonder and Premium Gem Peas. The Peas are of the very best quality, sweet and sugary. Seed wrinkled and green in color. Bu. $\$ 7.50, \mathrm{pk} . \$ 2.00$, cit. $30 \mathrm{c}$, pt. $20 \mathrm{c}$, pkt. $10 \mathrm{c}$.

Bliss'American Wonder The earliest dwarf wrinkled Pea, and a good bearer.

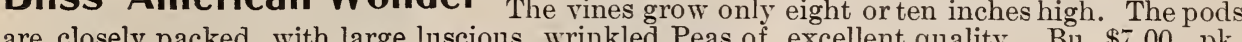
$\$ 1.85$, qt. $30 \mathrm{c}, \mathrm{pt} .20 \mathrm{c}$, pkt. $10 \mathrm{c}$.

Gradus or Prosperity This extra early, wrinkled Pea is simply a wonder in size Uradus or Prosperity of Pod and size of Peas; in habit of growth and in productivenesss. The vines grow about 30 inches high. The pods are 4 inches or more in length and contain 8 to 10 large luscious Peas. A grand Pea in all respects. Bu. $\$ 11.00$, pk. $\$ 3.00$, qt. $50 \mathrm{c}$, pt. $30 \mathrm{c}$, pkt. $10 \mathrm{c}$.

Extra Early Premium Gem A dwarf, early, wrinkled Extra Eaturing about 4 or 5 days after American Wonder. The vines grow about 15 inches high and are quite productive; pods about three inches long and well filled with Peas of delicious flavor. Bu. $\$ 6.25,1 / 4 \mathrm{bu} . \$ 1.75$, qt. 30c, pt. $15 \mathrm{c}$.

Surprise Gregory's This new, extra early, wrinkled Pea vine has a habit of growth like that of the early smooth-seeded sorts, but as it is a wrinkled Pea it is not quite so hardy and should not be planted quite so early. Bu. $\$ 6.25$, pk. $\$ 1.75$, qt. $30 \mathrm{c}$, pt. $15 \mathrm{c}, \mathrm{pkt} .10 \mathrm{c}$.

Telephone This is a tall-growing late sort. The vines are very strong growing, and continue in bearing a long is delicious; immensely productive and of the finest quality. Bu. $\$ 6.50$, pk. $\$ 1.75$, qt. $30 \mathrm{c}$, pt. $15 \mathrm{c}$, pkt. $10 \mathrm{c}$.

Champion of England This is the old standard late vaproductive. It is certainly one of the richest and best-flavored Peas. Height 4 to 5 feet; seed light green and much shriveled. One of the best of its season-either for the market or home garden. Bu. $\$ 4.25$, pk. $\$ 1.15$, qt. $25 \mathrm{c}, \mathrm{pt} .15 \mathrm{c}$, pkt. $10 \mathrm{c}$.

Black-Eyed Marrowfat An excellent variety, growing about 5 feet high. Very productive. $\mathrm{Bu} . \$ 3.25$, pk. $85 \mathrm{c}$, qt. $20 \mathrm{c}$, pt. $12 \mathrm{c}$, pkt. $10 \mathrm{c}$.

\section{Zion Horticultural SUPPLy,}

\section{Aresa, Wiș., April 7, 1904.}

Dear Sirs: We received the Dollar Collection of greenhouse plants and are delighted with them. I have bought plants nearly very spring and never received such nice ones before. I send you the brder of a neighbor to whom I showed them, and think I can get another order next week.

Yours with thanks, MRS. C. S. POPE。

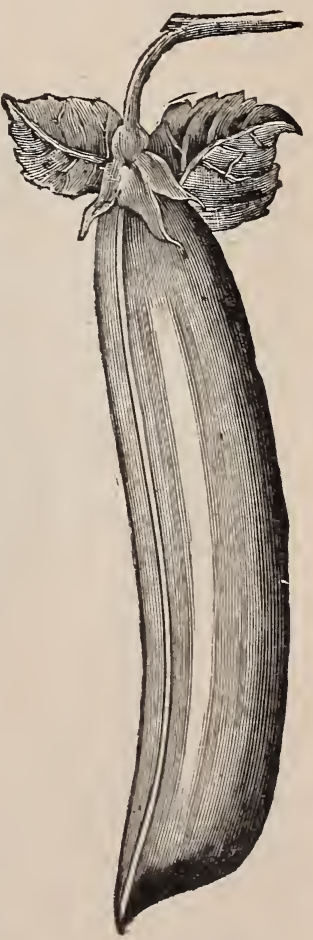

Telephone. 


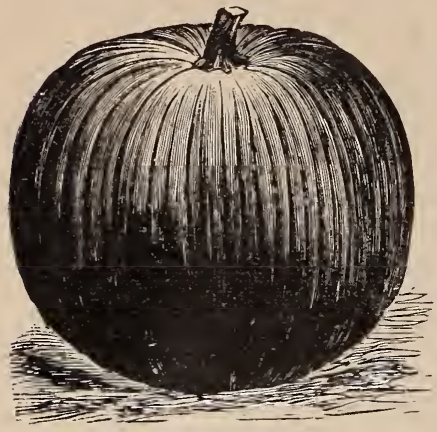

Winter Queen

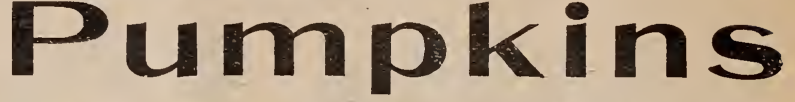

Winter Queen or Luxury

This is an improve ment over tho oid sugar pumpkin. The size is about 9 or 10 inches in dia. meter. In color a rich golden yellow, with a netted skin much resembling a potato. A good winter keeper. Lb. $80 \mathrm{c}, 1 / 4 \mathrm{lb} .25 \mathrm{c}$, oz. $10 \mathrm{c}$, pkt. $5 \mathrm{c}$.

\section{Large Field This variety is usually grown for among corn. It also makes splendid pies. Fruits very large, smooth, hard, orange skin and yellow flesh. $\mathrm{Lb}$. $45 \mathrm{c}, 1 / 4 \mathrm{lb} .15 \mathrm{c}$, oz. $10 \mathrm{c}, \mathrm{pkt} .5 \mathrm{c}$.}

Large Cheese Grows very large, shape flat like a cheese box. One of the best for family use and market. Lb. $60 \mathrm{c}, 1 / 4 \mathrm{lb} .20 \mathrm{c}$, oz. $10 \mathrm{c}$, pkt. $5 \mathrm{c}$.

Small Sugar A handsome prolific variety; fruits of small size, averaging about 10 Small Sugar inches in diameter, of good keeping qualities, flattened and slightly ribbed. Skin deep orange yellow, flesh rich and sweet. Lb. $75 \mathrm{c}, 1 / 4$ lb. 25c, oz. 10c, pkt. 5c.

\section{Radishes}

\section{Early Scarlet Globe}

One of the best bright red turnip radishes. An extremely quick-growing sort. Bright scarlet in color with small top. Good either for forcing or open ground. Lb. $80 \mathrm{c}, 1 / 4 \mathrm{lb}$. 25c, oz. $10 \mathrm{c}$, pkt. $5 \mathrm{c}$.

\section{Scarlet Turnip, White}

Tip A beautiful radish, just size. Their fine appearance makes them a quick seller. Tops and roots both small; flesh very mild and crisp $\mathrm{Lb}$. $65 \mathrm{c}, 1 / 4 \mathrm{lb} .20 \mathrm{c}, \mathrm{oz} .10 \mathrm{c}$, pkt. $5 \mathrm{c}$.
Improved French Breakfast

This scarlet, olive shaped, white-tipped radish is one of the most beautiful of all. Very quick grower and very tender $\mathrm{Lb}$. $65 \mathrm{c}, 1 / 4 \mathrm{lb} .20 \mathrm{c}$, oz. $10 \mathrm{c}$, pkt. $5 \mathrm{c}$.

\section{Long Brightest Scar.} let or Cardinal $\mathrm{Th}$ e somest and earliest long radish. Resembles the Long Scarlet. Lb. $60 \mathrm{c}, 1 / 4$ lb. $20 \mathrm{c}$, oz. $10 \mathrm{c}$, pkt. $5 \mathrm{c}$.

Early Long Scarlet, Short Top The standard ish. The roots are long, smooth and straight. Selected seed. Lb. $60 \mathrm{c}, 1 / 4 \mathrm{lb} .20 \mathrm{c}$, oz. $10 \mathrm{c}$, pkt. $5 \mathrm{c}$.

White Icicle The earliest long white radish, coming in the same time as Long Scarlet and resembling that variety in shape. Lb. $70 \mathrm{c}, 1 / 4 \mathrm{lb} .20 \mathrm{c}, \mathrm{Oz} .10 \mathrm{c}$, pkt. $5 \mathrm{c}$.

Cincinnati Market The tops of this variety grow much smaller than the tops of the ning to seed. This fact makes it a valuable variety for forcing. It is equally as good for the open ground. In color same as Long Scarlet. Lb. 60c, $1 / 4$ lb. 20c, oz. 10c, pkt. 5c.

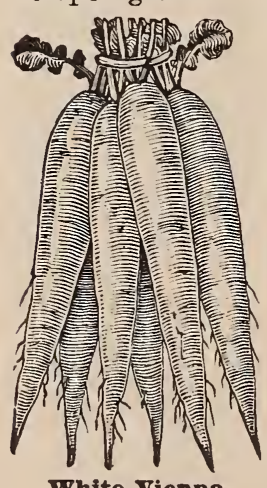

Long White Vienna, or Lady Finger A long white variety Scarlet. Very quick growing and remains in similar in shape to Long than most radishes. Good seller for early spring or summer use. Lb. $65 \mathrm{c}, 1 / 4 \mathrm{lb} .20 \mathrm{c}, \mathrm{oz} .10 \mathrm{c}$, pkt. $5 \mathrm{c}$.

Long White Strasburg A large white variety, half long, especilb. 20c, oz. 10c, pkt. 5c.

Rose China Winter A thick-growing ter; bright rose color and variety for winLb. $75 \mathrm{c}, 1 / 4$ lb. 20c, oz. 10c, pkt. 5 c.

Round Black Spanish A very popwith the Germans. Lb. $60 \mathrm{c}, 1 / 4 \mathrm{lb}$. 20c, oz. $10 \mathrm{c}$, pkt. $5 \mathrm{c}$.

LONG BLACK SPANISH. One of the hardWhite Vienna lest, keeping well until spring. Lb. $60 \mathrm{c}, 1 / 4 \mathrm{lb} .20 \mathrm{c}$, oz. $10 \mathrm{c}$, pkt. $5 \mathrm{c}$.

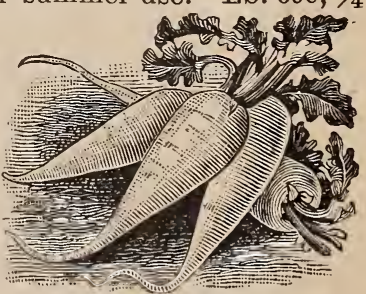

Long White Strasburg 


\section{SQUASHES}

Mammoth Yellow Bush This is the scallop or

Yery early. Thick yellow flesh with skin of a deep orange. Lb. 90c, $1 / 4$ lb. 80c, oz. 10c, Pkt. 5c.

Mammoth White Bush This is of the true bush growth, producing thick fruit with scalloped edges. Frequently grows to twelve or fourteen inches in diameter. Lb. $90 \mathrm{c}, 1 / 4 \mathrm{lb}$. 30c, oz. $10 \mathrm{c}$, pkt. $5 \mathrm{c}$.

Giant Summmer Crookneck

This well-known variety is quite as early as the Lb. $90 \mathrm{c}, 1 / 4 \mathrm{lb}$. $35 \mathrm{c}$, oz. 15 , Pkt. 5 c.

above, with large warty, yellow Crookneck fruits.

Boston Marrow This is a popular squash for fall and winter use. In color a bright Boston Marrow orange. Flesh yellow, rich and sweet. Oval form, thin skin and a good keeper. Unexcelled for pies. Lb. $\$ 1.10,1 / 4 \mathrm{lb} .40 \mathrm{c}, 0 \mathrm{z} .15 \mathrm{c}, \mathrm{pkt}$. $5 \mathrm{c}$.

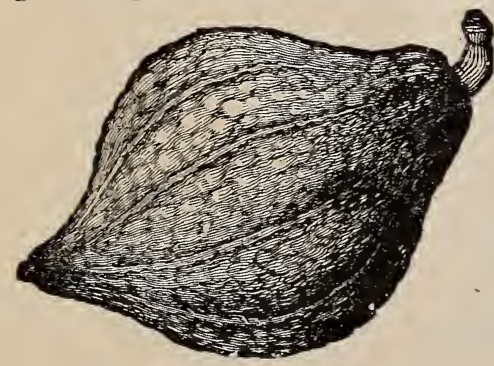

Hubbard An extra choice selection of this standard winter squash. More generally grown than any other variety. Fine grained and of excellent flavor. Lb. $\$ 1.00,1 / 4 \mathrm{lb} .35 \mathrm{c}$, oz. $15 \mathrm{c}$, pkt. $5 \mathrm{c}$.

Warted Hubbard This sort resembles the old Hubbard with the exception of a dark green, almost black skin, which is densely covered with knots or warts. It is of first-class quality.

Hubbard Lb. $\$ 1.15,1 / 4$ lb. $40 \mathrm{c}$, oz. $15 \mathrm{c}$, pkt. $5 \mathrm{c}$.

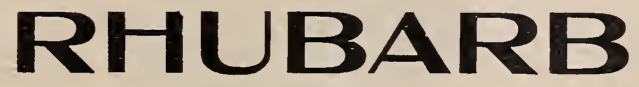

Mammoth Victoria If the seed of this variety is sown in spring, and the plants not transplanted but properly thinned, they will produce fine stalks for use the following season. Lb. $\$ 1.50,1 / 4 \mathrm{lb}$. $45 \mathrm{c}$, oz. $15 \mathrm{c}$, pkt. $5 \mathrm{c}$.

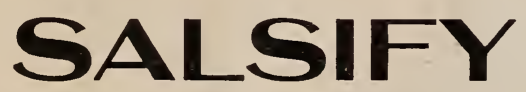

Mammoth Sandwich Is:and Grows double the size of the old Long White. The root is pure white, very thick and heavy, and of excellent quality. Lb. $\$ 1.20,1 / 4 \mathrm{lb} .35 \mathrm{c}$, oz. $15 \mathrm{c}$, pkt. 5c.

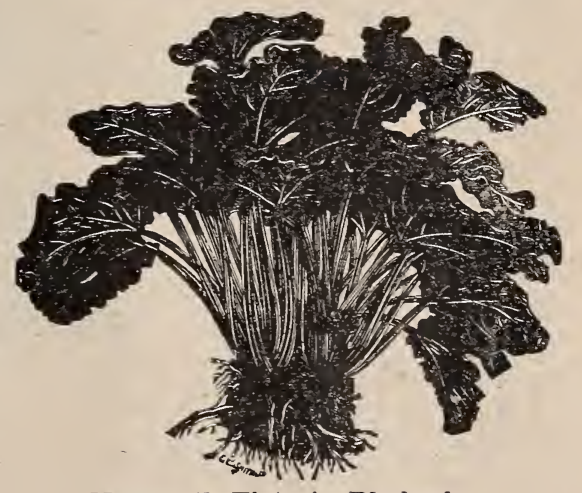

Mammoth Victoria Rhubarb.

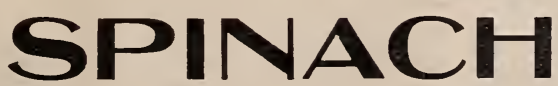

Extra Large Round Leaved Large, round, thick and fleshy leaved. Quite $1 / 4 \mathrm{lb} .12 \mathrm{c}$, oz. 10c, pkt.5c.

Bloomsdale or Savoy Leaved The earliest of all the varieties. The leaves of this cabbage. Lb. 30c, $1 / 4$ lb. 12c, oz. 10c, pkt. 5 c. Prickly Seeded A hardy variety used for fall sowing. With light protection it will 


\section{TOMATOES}

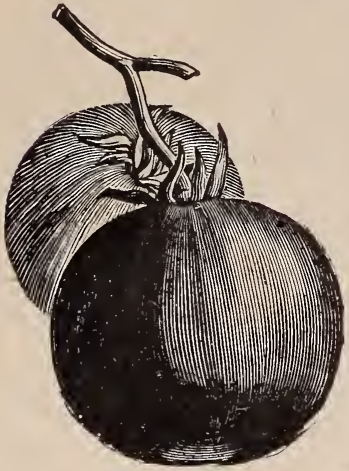

Improved Stone

\section{Improved Stone}

This is the standard for main crop and canning. Very productive, the fruits very smooth. If we could have only one main crop tomato it would be the Stone. Lb. $\$ 2.15,1 / 4$ lb. 65c, oz. $25 \mathrm{c}$, pkt. $5 \mathrm{c}$.

\section{Ground Cherry or} Husk Tomato ${ }_{\text {is not }}^{\text {Th }}$ a tomato, but is used for preserving, etc. It is also fine dried in sugar. The vine is of low spreading growth and the yellow fruit, which is the size of a cherry, is inclosed in a husk. Oz. $20 \mathrm{c}, 1 / 2$ oz. $12 \mathrm{c}$, pkt. $5 \mathrm{c}$.
Acme A fine solid, smooth early variety; medium in size, $\$ 2.25,1 / 4 \mathrm{lb} .70 \mathrm{c}$, oz. $20 \mathrm{c}$, pkt. $5 \mathrm{c}$.

Livingston's Beauty One of the smoothest and best of he large purple sorts. Vines $\$ 2.25,1 / 4$ lb. $70 \mathrm{c}$, oz. $20 \mathrm{c}$, pkt. $5 \mathrm{c}$.

Dwarf Champion This variety is generally called the and vigorous growth. The foliage is thick and heavy and of the darkest green. It is an early variety and though not of the largest size, it is an immense bearer and the fruits are as smooth as an apple. We think much of this variety. Lb. $\$ 3.25,1 / 4$ lb. $90 \mathrm{c}$, oz. $30 \mathrm{c}$, pkt. $5 \mathrm{c}$.

Early Michigan A good variety for the general market or Early for fame, of uniform size and regular shape. For freedom from rot and cracking, this variety is unsurpassed. The first fruits are very early, the vines continue a long time in bearing, the

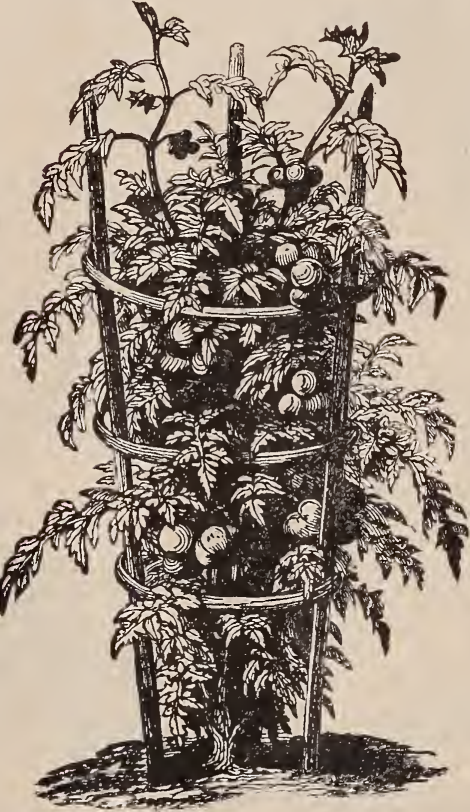
fruits growing larger instead of smaller as the season advances, flesh solid, without any core. Well adapted for summer use. Lb. $\$ 2.60,1 / 4$ lb. $75 \mathrm{c}$, oz. $25 \mathrm{c}$, pkt. $5 \mathrm{c}$.

Yellow Peach a yellow, good for preserving. Lb. $\$ 2.25,1 / 4 \mathrm{lb}$. $70 \mathrm{c}, \mathrm{Oz}$. $20 \mathrm{c}$, pkt. $5 \mathrm{c}$.

\section{Ponderosa}

The more we see of this tomato the better we like it. Some of the fruits are irregular in size, but the size is so immense, the flesh so solid, the flavor so mild, the vines so productive, we overlook a few rough specimens. We also find that if it is planted early it is about as early as any variety. Lb. $\$ 4.50,1 / 4 \mathrm{lb} . \$ 1.25, \mathrm{oz}_{\mathrm{c}}$ $45 \mathrm{c}$, pkt. $10 \mathrm{c}$.

\section{TURNIP Early Purple Top Strap Leaf \\ This early variety is a great favorite for table use. Flat, medium size, purple above} ground, white below. Lb. 50c, $1 / 4$ lb. 15c, oz. 10c,pkt. 5c. Purple Top White Globe Much like the above, except in globe-shaped. Good either for table or stock feeding. Lb. 50c, $1 / 4 \mathrm{lb}$. 15c, oz. $10 \mathrm{c}$, pkt. 5 c.

White Flat Dutch A most excellent variety for the garden Roots medium size flat: color and largely used in the Southern states. $50 \mathrm{c}, 1 / 4 \mathrm{lb} .15 \mathrm{c}$, oz. $10 \mathrm{c}$, pkt. $5 \mathrm{c}$.

Monarch Rutabaga Some people prefer the Rutabaga to variety grows to any other Swede. It is also very sweet, making it very valuable for feed-

ing stock. Lb. 50c, $1 / 4$ lb. 20c, oz. 10c, pkt. 5c. This is a purple top variety of the largest size, best shape, with small neck and smooth skin, good cropper and keeper. Lb. 50c, $1 / 41 \mathrm{lb} .20 \mathrm{c}, 0 \mathrm{z} .10 \mathrm{c}, \mathrm{pkt} .5 \mathrm{c}$

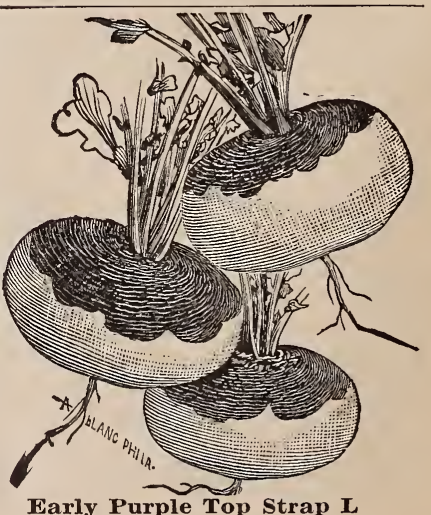




\section{POTATOES}

We offer only a few standard varieties of Potatoes but those which we offer, are, we believe the best that are now grown for market. Our seed has been grown in the Red River Valley of the North; in a soil and climate that is expressly adapted for producing well-developed tubers of strong vitality. We can sell Wisconsin-grown stock at a little less than the prices here quoted.

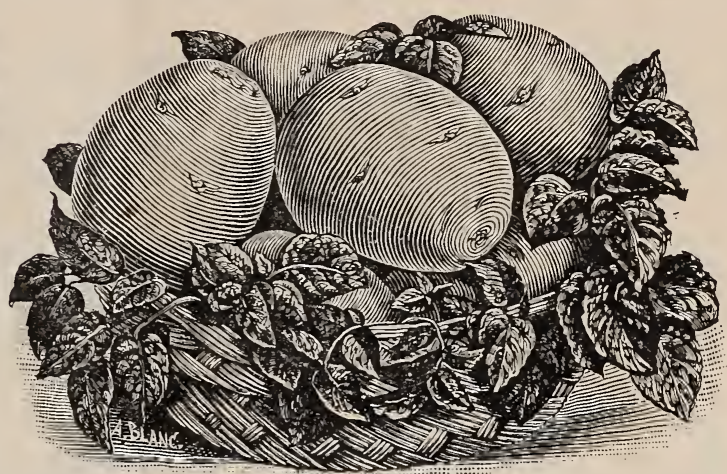

Improv varieties of Potatoes come and go, but it seems the Early Improved Early Ohio Ohio goes on forever. Those who want the most profitable Potato for early use or market are still asking for the Early Ohio. The Potato is nearly round in shape, with few eyes and scarcely any small Potatoes. The stalk is vigorous, and upright in growth, can be planted closer both in hill and row than any other variety. This Potato comes so early as to escape both drouth and blignt. Bbl. $\$ 4.00$, bu. $\$ 1.40,1 / 2$ bu. $85 \mathrm{c}$, pk. 50c. By mail, lb. 25c, 3 lb. 50c.

Acme This is an early variety of the Ohio class and is identical with the kind called Early Ohio. This you can tell by testing the two together. Prices same as Early Ohio.

Farly Rose This well-known variety is still sought after by many. It comes in the class Early Rose of the second early. We offer only Wisconsin stock of this variety. Bbl. $\$ 3.75$, bu. $\$ 1.40,1 / 2$ bu. $80 \mathrm{c}, \mathrm{pk}$. $45 \mathrm{c}$.

Farly Beauty of Hebron This is a fine early variety, oblong in shape, skin white about the same time as Early Rose. Bbl. $\$ 3.75$, bu. $\$ 1.40,1 / 2 \mathrm{bu} .80 \mathrm{c}$, pk. $45 \mathrm{c}$.

Rural New Yorker It is very large, usually smooth with few and shallow eyes. In Rural New Yorker quality unexcelled. It is the best late long keeper and we recommend it highly. No doubt there are more Potatoes of this variety sold for table use each year than of any other sort. Their large handsome appearance always commands a ready sale at top prices. Bbl. $\$ 3.75$, bu. $\$ 1.40,1 / 2$ bu. $80 \mathrm{c}$, pk. $45 \mathrm{c}$. By mail, $1 \mathrm{lb} .20 \mathrm{c}, 3 \mathrm{bls}$. $50 \mathrm{c}$.

Carman, No. 3 This variety of the Rural family is immensely popular. It is a splendid main crop Potato. It makes great yields of fine smooth tubers even under unfavorable circumstances and can be relied upon to bring in money. It grows with strong upright stalks and is little affected by drouth, blight, or bugs. Prices same as Rural New Yorker.

\section{Vegetable Plants from Seed}

Our Vegetable Plants are grown in hotbeds, transplanted and hardened off. If wanted by mail, add 5c per dozen and 20c per hundred to the following prices:

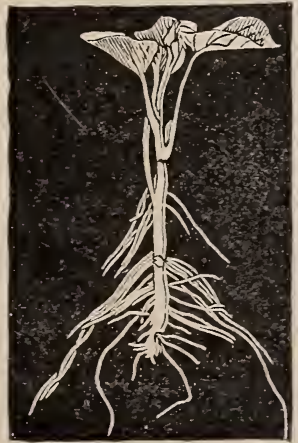

CABBAGE, EARLY. Ready Apr. 15th. Early Wakefield, E a r ly Spring and All-Head Early. Per $1,000 \$ 4.50 ; 100$ 60c; doz. 12c.

CAULIFLOWER, EARLY. Ready April 15th. Early Snowball. Per $1,000 \$ 6.00 ; 10080 \mathrm{c}$; doz. 20c.

CELERY, EARLY. R e a dy in June. White Plume, Golden SelfBlanching, Golden Heart, Giant Pascal, and Turnip Rooted. Per $1,000 \$ 3.50 ; 10045 \mathrm{c}$.

EGG PLANT. Ready May 15th. Prices same as tomatoes.

PEPPERS. Ready May 15th. Sweet Mountain, Ruby King, Bell or Bull Nose and Cayenne. Per $1,000 \$ 6.00 ; 100 \div 5 \mathrm{c}$; doz.15c.

SWEET POTATO. Ready about May 15 th to 20 th. Yellow Jerseys and Red Jerseys. Per 1,000 \$2.50; 10035 c; doz. 10c.

TOMATO. Ready M a y 15th. D w a r f Champion, Ponderosa, Stone and Beauty. Per $1,000 \$ 6.00$; $10075 \mathrm{c}$; doz. $15 \mathrm{c}$.

LETTUCE. Transplanted plants from Grand Rapids Forcing, and Hanson. Per 100 80c; doz. 10c.

CHIVES. Clumps e a ch 10c, doz. \$1.00. By mail, each, 10c extra.

HORSERADISH SETS. Pe r $10075 \mathrm{c} ; 50$ 50c, postpaid; 500 $\$ 3.00$ by express.

RHUBARB ROOTS. L a $\mathrm{r}$ g e strong seedlings, each 10c, dozen $\$ 1.00$.

Place your orders early. All prices quoted are money = savers. Do it now. 


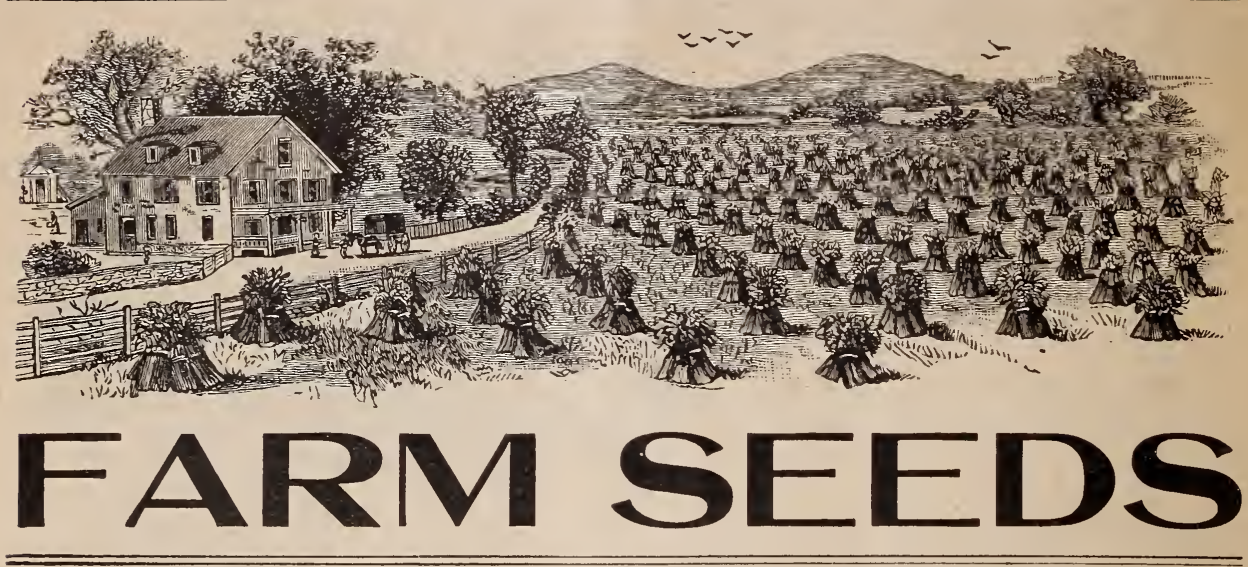

\section{FIELD CORN}

PRIDE OF THE NORTH. The earliest Yellow Dent of good size. Will make a crop farther north than any other sort. Will mature in 90 days of good corn weather. Bu. $\$ 2.00$, pk. 60c, qt. 25c, pkt. 10c. Postpaid, qt. 35c, pt. 25c, pkt. 10c.

LEAMING. A standard Yellow Dent, the ears measure 9 to 11 inches and nearly always two ears on a stalk, deep grains and small red cob. Ripens in 110 days of good weather. $\mathrm{Bu} . \$ 1.75$, pk. 50c. Postpaid, qt. $30 \mathrm{c}$, pt. 20c, pkt. $10 \mathrm{c}$.

IOWA SILVER MINE. This is the best standard White Corn in existence surpassing in yield all other kinds. Those who are looking for a large yield will do well to plant this variety. Bu. $\$ 1.75, \mathrm{pk}$. 55c. Postpaid, qt. 35c, pt. 20c, pkt. 10c.

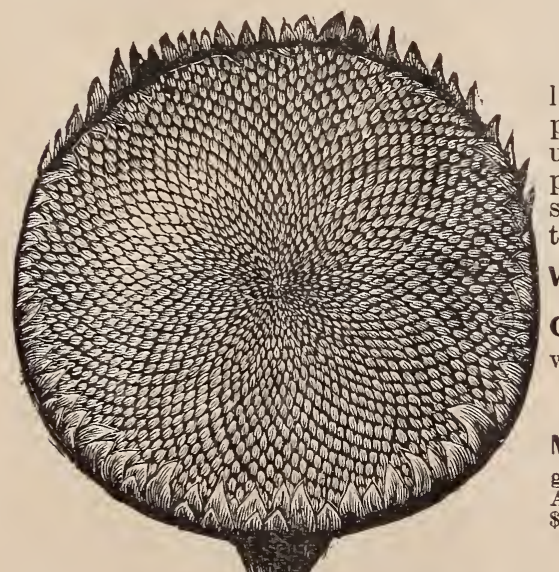

WISCONSIN YELLOW DENT. This is a main crop Yellow Dent. It has been carefully selected and has as deep a grain and as large a percentage of grain to cob as it is possible. Bu. $\$ 2.00$, pk. 60c. Postpaid, qt. $35 \mathrm{c}, \mathrm{pt} .25 \mathrm{c}$, pkt. $10 \mathrm{c}$.

LONGFELLOW FLINT. A beautiful and round Yellow Flint. Ears from 10 to 15 inches long, very prolific. Bu. $\$ 2.25$, pk. 65c. Postpaid, qt. 35c, pt. 25c, pkt. 10c.

\section{POP CORN}

WHITE RICE. The most popular for general use. The grain is pointed, pops white, is full, very productive and of excellent quality.

QUEEN'S GOLDEN. It pops pure white, and a single kernel will expand nearly one inch. Either kind not prepaid, $10 \mathrm{lbs} .65 \mathrm{c}$, 5 lbs. 40c, 1 lb. 12c. Postpaid, lb. 20c, pkt. 5c.

\section{COW PEAS}

Cow Peas have come into great prominence in the last few years because of their great value in improving poor soil. A crop of green forage plowed under is one of the best and cheapest ways of improving the soil. For this purpose they should be sown in May or June and plowed under as soon as they have attained their full growth.

WHIP.POOR-WILL. This is the variety usually grown. Bu. $\$ 2.00$, pk. $65 \mathrm{c}$.
VANA CANADA FIELD PEAS. for cattle-feeding. Often sown with oats and cut green. Bu. $\$ 1.75$, pk. $65 \mathrm{c}$.

\section{SUNFLOWER} MAMMOTH RUSSIAN. This variety is enormously progrow to an immense size often measuring 18 inches in diameter. An excellent and cheap food for fowls. $100 \mathrm{lbs}$. $\$ 5.00,25 \mathrm{lbs}$. $\$ 1.50$. By mail, per $\mathrm{lb}$. 18c.

\section{ESSEX RAPE}

A forage plant of highest value. Sow in April for early crop, and in July, August and September for Fall crop. In a few weeks after sowing sheep or cattle can be turned upon it. All reports agree that they gain weight faster on this than any other fodder. $100 \mathrm{lbs}$. $\$ 5.00$, bu. of $50 \mathrm{lbs}$. $\$ 3.00$. Per lb. by mail 18c.

Mammoth Russian.
BUCKWHEAT, OATS, ETC. The margin of profit is so small, and the prices so subject to the fluctuations of the market that we do not list a full line of Farm Seeds but will give quotatious by mail at any time. 

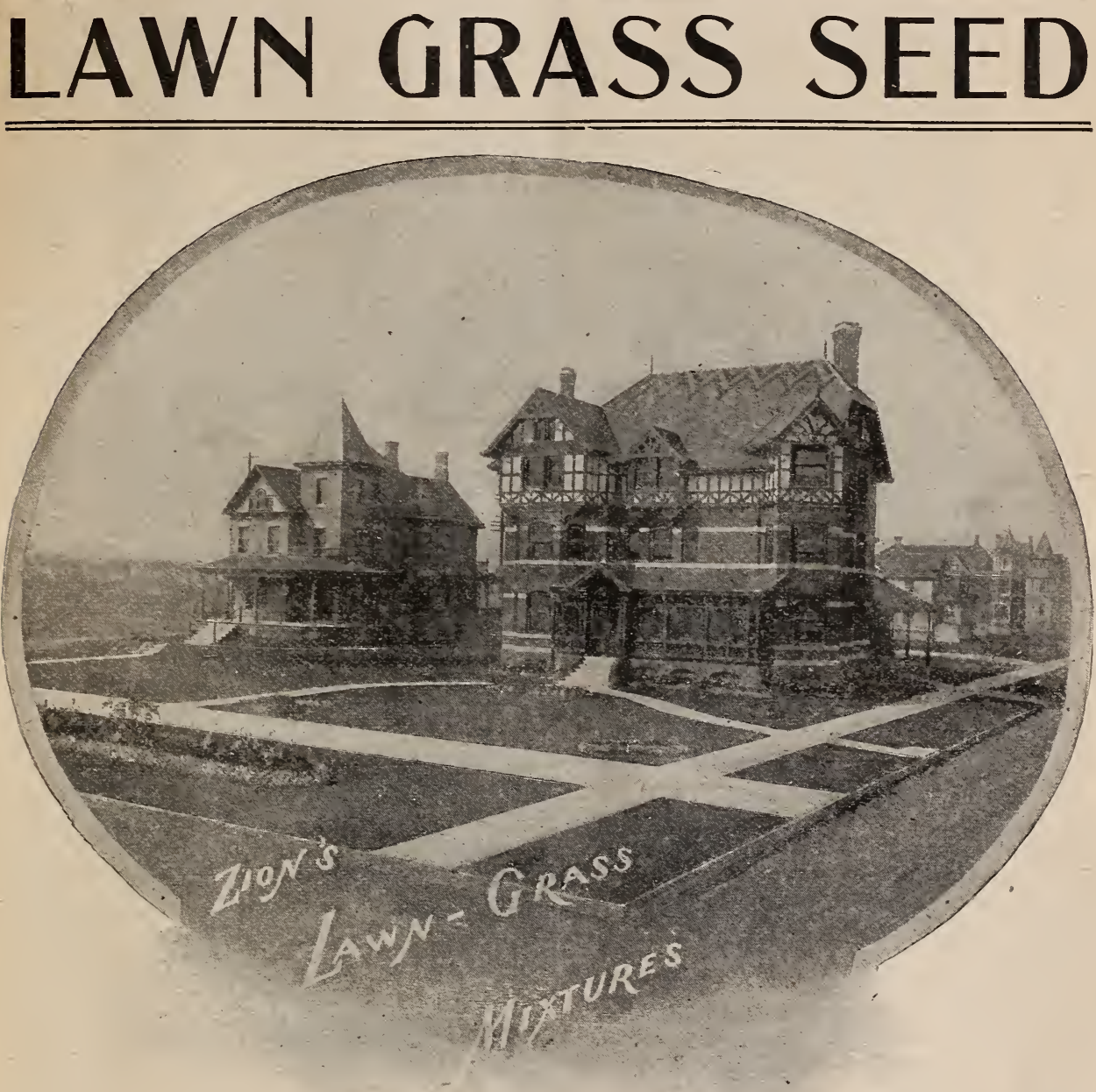

\section{HOW TO MAKE A LAWN.}

A lawn may be established either by sodding or seeding. The latter is not only less expensive, but more satisfactory, as better grasses can thus be obtained. We have noticed that sod taken from old pastures often contains dandelion seeds which give much trouble in the lawn. This does not bother in a lawn which is made by seeding. It is useless to sow lawn grass seed on land that has not been properly prepared and enriched. If stable manure is used it should be well rotted, otherwise many obnoxious weeds will come in. Bone meal and Nitrate of Soda are standard fertilizers for the lawn. For fuller and more minute directions for lawn making read Garden Making, advertised on another page.

Shiloh Park Mixture $\begin{gathered}\text { The foundation of } \\ \text { this mixture, as }\end{gathered}$ with nearly all lawn grass mixtures, is Kentucky Blue-grass, with enough early and quick-growing and lasting varieties to produce an effect at once and also to produce a lawn which will retain its rich green color throughout the season. With frequent showers or with provision for watering, a beautiful lawn can be produced within a few weeks with this mixture $\mathrm{Bu}$ $\$ 4.50$, pk. $\$ 1.25,1 b .25$ c. If by mail add $8 \mathrm{c}$ per $\mathrm{lb}$. Velvet Lawn Mixture This is a perfectly those who want something a little cheaper than the Shiloh Park Mixture. 13u. (18 lbs.) \$3.75, pk. $\$ 1.00,1 \mathrm{~b} .20 \mathrm{c}$.
Kentucky Blue-grass Also known as the finest pasture grass, suited to meadows and rich lands; a perfect lawn grass. Bu. (14 lbs.) $\$ 3.50$, pk. $\$ 1.00,1 \mathrm{~b} .18 \mathrm{c}$

Red Top or Herds Grass Suitable for pasture mixtures or for exclusive use in lawn making. Bu. (10 lbs.) $\$ 1.50$, lb. $16 \mathrm{c}$, by mail $24 \mathrm{c}$

Timothy. Too well-known to need description. Timothy. Bu. market price, lb. 10c, by mail $18 \mathrm{c}$

White Dutch Clover tures. in lawn mixmail 38c. Prices of other grass seeds given on application.

NEW BLOOD 'OF STANDARD SORTS AND NOT NEW VARIETIES IS WHAT YOU WANT IN THE POTATO FIELD. OUR SEED POT.ITOES GROWN IN THE RED RIVER VALLEY ARE VIGOROCS AND FREE FROM DISEASE. SEE PAGE 15. 


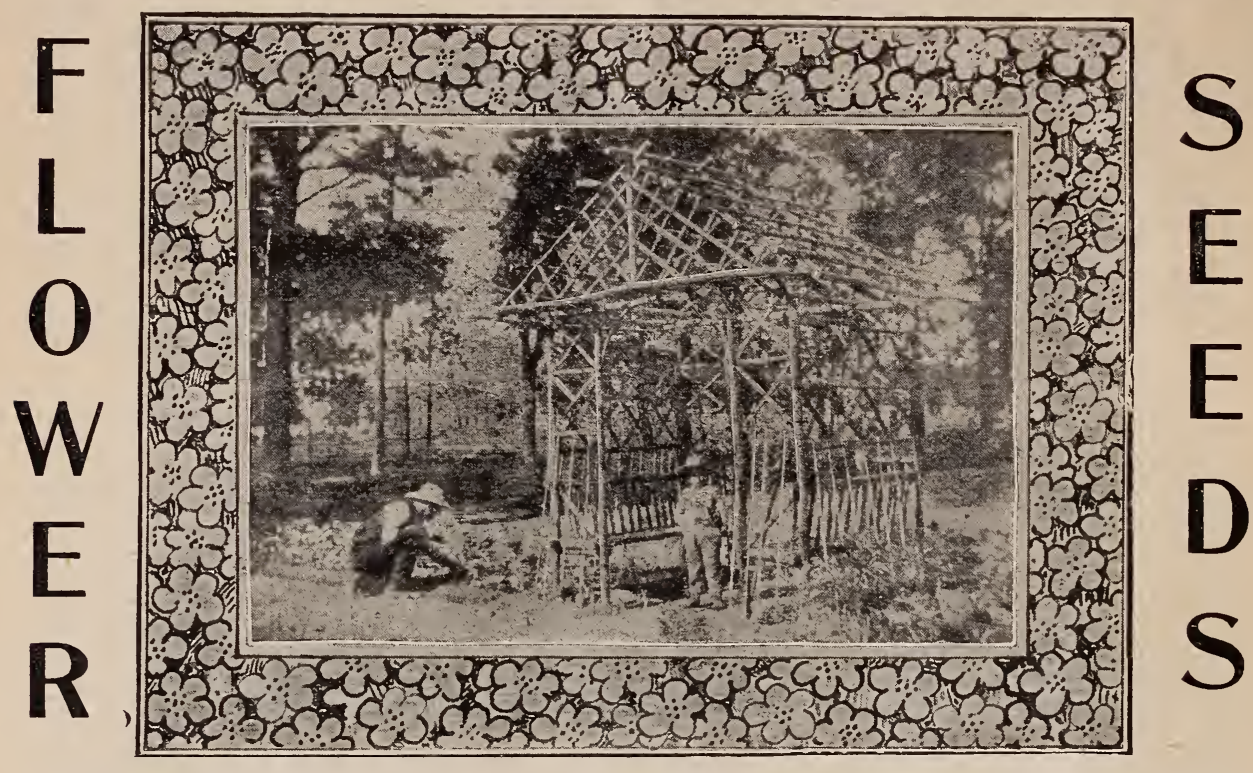

Our Flower Seeds are put up in uniform five-cent packages, except some rare or expensive kinds where the price will be noted. Many complaints are made of poor seeds when the only fault is in careless sowing.

We desire all our customers to have the greatest possible success with our Flower Seeds, and while we have not the space to give explicit directions for every variety, the following suggestions will be of great benefit to all who will follow them: For all seeds which should be started indoors, including Heliotrope, Lobelia, Salvia, Vinca, Verbena, etc., the best plan is to sow in shallow boxes or earthenware seed pans about two inches deep. The lower part should be filled with coarse soil, coal ashes or any rough material to give proper drainage. The upper inch should be of finely sifted soil, composed of about one-third each of leaf mold, sand and light garden loam. Firm this evenly and water thoroughly the day before sowing. Sow the seed thinly over the surface, covering about oneeighth of an inch and pressing firmly; cover with a pane of glass or one or two thicknesses of paper and keep the temperature between 60 and 70 degrees. Water carefully as needed. Do not keep the soil sodden and do not neglect a single watering when it is needed. To allow the soil to become dried out only once is sure to cause failure. Remove the covering when the seeds have germinated. When the seedlings are large enough to handle they should be transplanted to other boxes an inch apart each way. If the young seedlings rot off at the surface of the ground they have had too much water and not enough air.

Most of the ordinary annuals such as Sweet Alyssum, Calliopsis, Mignonette, Phlox, Nasturtium, etc., may be sown directly out of doors as soon as danger of frost is past, in the place where they are to grow. Rake the ground fine and sow the seeds thickly, covering about four times their size and pressing the soil firmly over them. Should they come up too thickly, thin out and transplant so they will stand from four to twelve inches apart, according to the variety. Seeds of most Hardy Perennials may be sown at any time from January to October. Pansies especially do well when sown in the fall, and wintered over by covering with brush or straw or kept in cold frames.

Bulbs for Forcing and Spring Blooming. We shall issue about Sept. 1, 1905, a full catalog of Tulips, Hyacinths, Narcissus, and other Fall Bulbs, also other seasonable Plants and Seeds. Send for it. 


\section{GENERAL LIST OF}

\section{ACROCLINIUM}

A pretty annual "everlasting", with lovely white or rosy pink flowers, which if cut in the bud state can be dried and used in winter bouquets. Mixed colors.

\section{ADLUMIA}

Mountain Fringe or Allegheny Vine. A graceful, hardy climber, with feathery foliage and tube-shaped, flesh-colored flowers which completely cover the plant.

\section{AGERATUM}

One of the best bedding plants that can be grown from seed. Very easily grown from seed, and when it comes into bloom it continues throughout the whole season. For early blooming it should be sown in March. It is also valuable for winter blooming.

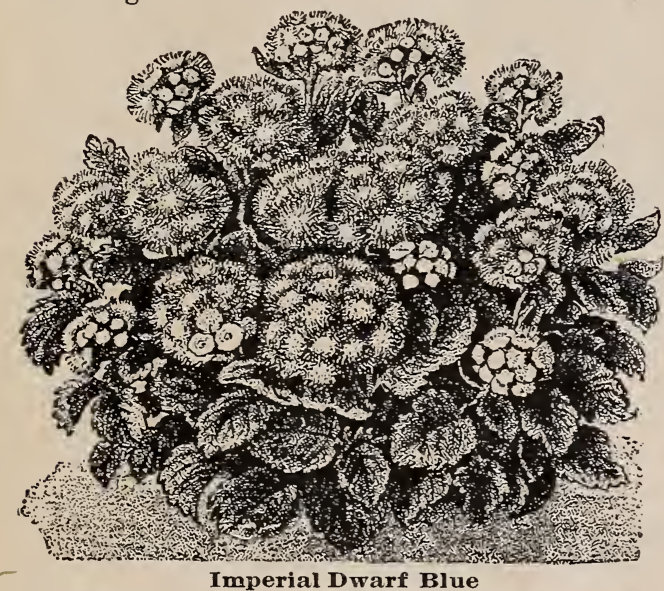

IMPERIAL DWARF BLUE. Blue perfection. Color deep amethyst blue.

IMPERIAL DWARF WHITE. Color pure white, very beautiful.

\section{SWEET ALYSSUM}

This is certainly the best border or edging plant that can be grown from seed, forming a compact plant only four to six inches in height and spreading from fifteen to twenty inches, and covered with a solid mass of pure white flowers from spring until late in autumn. The best variety of all is the Little Gem.

LIT TLE GEM. The plants begin to bloom when quite small, and are completely covered with snow-white blossoms. We know of no other white flowers so adapted to borders or ribbons as our "Little Gem" Alyssum. Will bloom all summer until late in the fall.

MARITIMUM. Of trailing habit; flowers white and very fragrant. Fine for cutting.

\section{FLOWER SEEDS}

\section{AMARANTHUS}

Brilliant foliaged annuals growing from three to four feet high. Useful for centers of flower beds or for tall borders. May also be grown as window plants.

TRICOLOR, (Joseph's Coat). Leaves red, yellow and green.

SALICIFOLIUS, (Fo untain PIant). Highly decorative, graceful, drooping, willow-shaped leaves, handsomely marked with orange, carmine and bronze. Pkt. 5c.

AMARANTHUS CAUDATUS, (Love Lies Bleeding). A tall slender plant with quantities of long drooping dark red flowers. Is a generous bloomer until late in the fall.

\section{ANGROSTEMMA}

CORONARIA, (Mullein Pink). Silver white foliage, crimson flowers.

\section{ANEMONE}

The Anemones are extremely pretty and perfectly hardy. They have all the colors of the rainbow, also black and white with markings. A good house plant for winter blooming. Handsome toliage.

\section{AQUILEGIA}

COLUMBINE. A hardy perennial, suitable for the open garden or for rockwork, blooming in May and June, forming large clumps and remaining from year to year. They grow from 1 to 3 feet high, bearing countless numbers of long, showy, spurred flowers of many shades and colors.

AQUILEGIA MIXED. Many colors of both double and single. Pkt. 5c.

\section{ASPARAGUS}

Extremely pretty greenhouse plants of highest decorative value, grown for the beauty of the foliage which is much used in bouquets.

SPRENGERI. Especially adapted for hanging baskets. 10 seeds $10 \mathrm{c}$.

PLUMOSUS NANUS. Commonly called Asparagus Fern. A greenhouse climber, also fine for a pot plant. The graceful feathery foliage of this variety rivals the Maiden Hair Ferm in beauty. 5 seeds $10 \mathrm{c}$.

\section{ANTIRRHINUM.}

This is one of the old-fashioned favorites commonly called Snapdragons. It is one of our most showy perennials, blooming the first year as annuals. The dark glossy leares and brilliantly colored flowers make a bright spot in the garden. Colors, white, scarlet and yellow. Will bloom abundantly until after frost. Useful for cutting, keeping fresh a long time.

WHITE. Pure white, beautiful for cutting. A great farorite.

TOM THUMB. Dwarf, many colors mixed. 


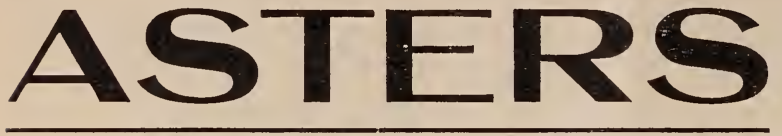

early, medium and late flowering sorts, which extend the blooming period from early in
July until frost. For the best results, the ground for the cultivation of Asters cannot be too July until frost. For the best results, the ground for the cultivation of Asters cannot be t
richly prepared, although they will give satisfactory returns on any ordinary garden soil.

Plants from seed sown in the open ground in May bloom well in September and October, when the flowers are seen at their best. For July and August flowers, sow in March or April, in cold frame, spent hotbed, or pots or boxes in the house.

\section{TRUFFANT'S PEONY FLOWERED PER-}

FECTION. Very large double flowers with incurved petals. All colors mixed.

QUEEN OF THE MARKET. The best early'Aster, usually in full bloom two weeks before most other sorts begin to bloom. Of graceful spreading habit. Height, $1 \frac{1}{2}$ feet. White, crimson, scarlet, light blue, mixed, in separate packets.

VICK'S BRANCHING. This vigorous type forms broad, handsome bushes covered with large, long-stemmed, longpetaled flowers that are graceful and feathery in effect. Mixed colors.
DAYBREAK. A new pink, fine for pots. It is one of those rare gems that come to stay. The flowers are round as a ball, the color a charming sea-shell pink.

PURITY. This new Aster is identical with the Daybreak only that the blossoms are pure white. Massed with the Daybreak nothing is more beautiful.

VICTORIA. Plants of this magnificent race bear from 10 to 20 beautifully reflexed flowers in an elegant pyramid about 18 in. high. The best sort for pot culture.

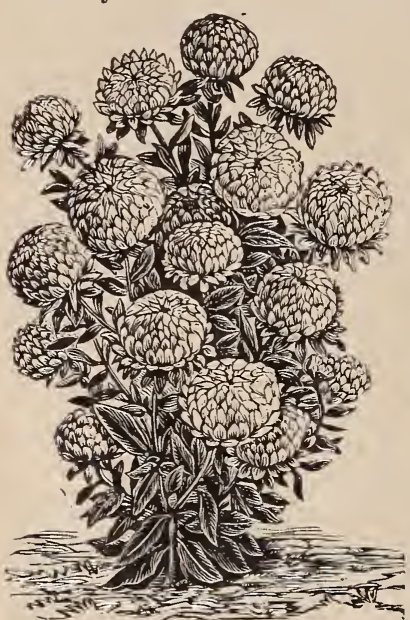

A L L I O

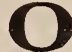

This is one of the garden's great forces in yellow; changing to rich red browns and maroons. A plant that is always desired in any garden. Sow in the open ground in the spring and give the plant plenty of room to spread. Stake and tie if necessary. Fine for cutting.

GOLDEN WAVE. Plant very bushy and compact, about two feet in height and covered from July to October with beautiful golden blossoms.

CALLIOPSIS. All sorts and colors mixed.

\section{CALENDULA}

GRANDIFLORA, (Orange King). A double yellow variety the most beautiful of double Marigolds.

DOUBLE WHITE. Similar to Grandiflora except of a pure white.

METEOR. Beautiful flowers with orange stripes on pale yellow ground.

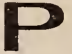

\section{BALSAMS}

IMP. DOUBLE CAMELIA FLOWERED. Mixed flowers of extraordinary size, double to the center. The most elegant TALL DOUBLE. Mixed colors.

\section{BEGONIAS}

\section{BRACHYCOME}

\section{BROWALLIA}

BROWALLIA MAJOR. A beautiful blue variety of the
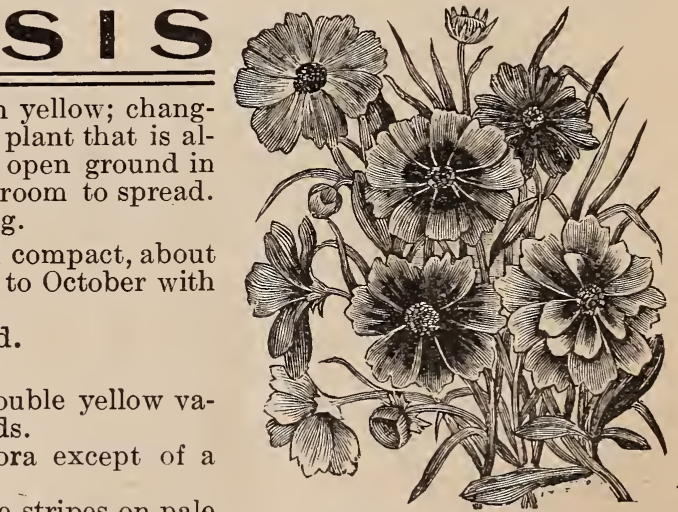

Calliopsis Mixed. 


\section{CALCEOLARIA}

Highly ornamental greenhouse or window plants, producing richly colored pocket-like flowers in abundance in the spring. The colors are yellow, brown, maroon and even crimson, and the flowers are often beautifully spotted and blotched. Sow seeds on the surface of light soil or leaf mold.

\section{CAMPANULA}

CANTERBURY BELLS. Perennial plants that favor, and which rank among the best of the oldfashioned. Two feet or more in height; profuse and constant bloomers. Beautiful, bell-shaped flowers and pretty foliage. May be grown in pots as window plants. Sometimes called cup and saucer.

Single and double varieties.

\section{CANARY BIRD VINE}

This vine is of the Nasturtium family, an excellent climber and good rambler for rockeries, stumps, etc. Has clear yellow flowers in abundance, an excellent vine for winter if grown in pots.

\section{CANDYTUFT}

The Candytufts are among our best white flowers for edgings, for bedding or massing, for rockeries and for cutting. Several of the varieties are fragrant, and all are profuse in bloom. Sow outdoors in April, where they are to bloom, and thin well when the plants are an inch high. Sow again in July for fall flowers.

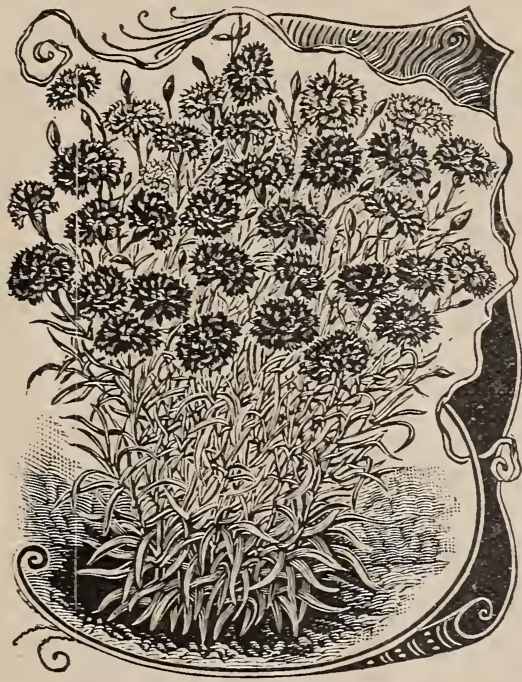

Marguerite Carnation. Stalks nearly black
SPLENDID MIXED.

ZANZIBARENSIS. The plants attain a height The ef twelve to fourteen feet. plant makes a perfect pyramid of foliage, thickly set from top to bottom with gigantic leaves. The difference between the varieties is in the coloring of the grand bamboo-like stems and long slenderleaf stalk. SANGUINEUS. Red stalks, scarlet fruit, six feet. CAMBODGENSIS. Large palm-like leaves of a

\section{CELOSIA}

This showy annual is of the easiest culture, and is one of the most showy of our summer flowers. The great masses of flowers vary great$l y$ in shape, from that of a brilliant cockscomb to that of a graceful feather or plume. The colors range from the most vivid red and crimson to the richest yellow and orange. TALL MIXED. All the tall and plumed varieties mixed.

DWARF MIXED. Cocksand other dwarf varieties mixed.

\section{CENTAUREA}

This interesting genus of plants embraces annuals, biennials, and perennials, which, though botanically alike, differ greatly in appearance. Some are grown for their silvery white, velvet-like foliage, others for the beauty of their flowers.

CANDIDISSIMA. Th is cANDIDISSIMA. variety is of low spreading growth, wain densely covered with white hairs

GYMNOCARPA. More upright in growth than The abore, with leares someedging Canna beds.

IMPERIALIS. This beautiful flower is a great . improvement over the old Corn Flower or Bachelor's Button. The fragrant Dlooms are 2 to 3 inches across. Height one to two feet. Excellent for bouquets, various shades of yellow, white, rose and lavender, etc.

\section{CHRYSANTHEMUM}

\section{CANNA}

Cannas will bloom the first year from seed if sown early in the house. The seed is very difficult to germinate, the seeds should have a notch filed or cut on one side and soaked in hot water 24 hours before sowing

STANDARD MIXED. A good mixture of the CARNATION

We consider the Marguerite to be about the only satisfactory carnation for outdoor planting, which can be grown from seed. The flowers will come double and semi-double, but all will be fragrant and beautiful.

MARGURITE MIXED, A very good mixture. Mc per pkt.

GIANT MARGURITE.A great improvement on the above. $10 \mathrm{c}$ per pkt. 100 seeds.

\section{RICINUS (Castor Oil Bean.)}

Planted either in beds or a hedge, or a single plant. Ricinus is one of the most showy of our garden beauties. The glistening leaves show a variety of colors, and seen from a distance form a striking picture of form and color.
Double and single mixed (annual sorts) No annual furnishes so many cut flowers as these, which hloom generously all summer, with endless possibilities of color, size, and beauty.

\section{CINER - ARIA}

HYBRIDA. Large Flow briliiant flowers are easily g row $n$ from seed, require iittle heat, are free - blooming with beautiful flowers in a variety of colors. For winter blooming they should be sown in August or September.

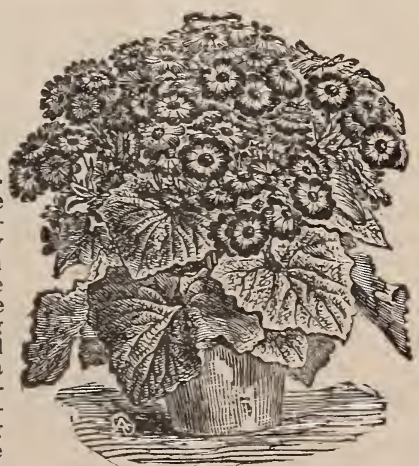

Cineraria. ering. These 


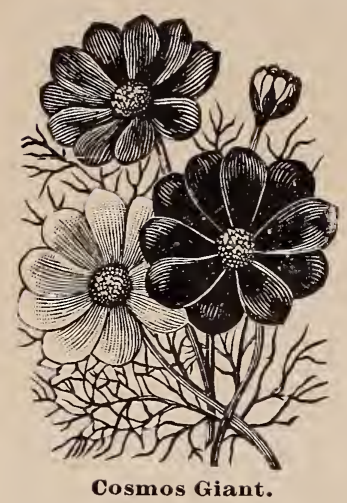

\section{CLEMATIS}

C. PANICULATA. A rapid climber, graceful in habit, with an abundance of feathery white blossoms in large clusters.

LARGE FLOWERING. Beautiful climber with lovely flowers, blue, white, purple, etc. Hardy, can remain in a permanent situation.

\section{COLEUS}

The best known and most popular of ornamental foliage plants. The leaves are of many shades of color having a rich velvety appearance of great beauty. No lawn should be without these beautiful decorative plants. Tender perennial.

\section{CONVOLVULUS}

MORNING GLORY. Beautiful and free blooming climbers. Growing purple, etc., the most popular clin in any situation. Colors, blue, pink, white, IMPERIAL JAPANESE. An especially beautiful variety with flowers tions. A very desirable climber.

\section{COSMOS}

Very effective autumn flowering plants. Hardy and rapid-growing, forming bushy plants with large single dahlia-like flowers. Start seed in March and transplant in July, or sow in open ground in April.

GIANT FLOWERED. A beautiful strain with extremely large flowers, white, pink, mauve, crimson, etc. Certain of the fringed forms resemble California Poppies with broad petals of great
beauty.

WHITE. Large pure white flowers.

EARLY DAWN. Dwarf, large flowering, growbeginning to

\section{CYPRESS VINE}

A most beautiful climber with delicate feathery foliage, and an abundance of bright star-shaped rose, scarlet or white blossoms, which contrast most beautifully with the graceful foliage.

\section{DAHLIA}

The Dahlia has always been a favorite for autumn flowering. The flowers are perfect in shape and have a large range of colors, so are always popular where display is wanted. Both the single and double varieties of these magnificent flowers may be grown from seed. Tender perennials.

\section{DOUBLE MIXED.}

\section{SINGLE MIXED.}

\section{DATURA (Trumpet Flower)}

Very showy, large, trumpet-shaped flowers, beautifully colored. The seed should be started indoors or under glass, for early blooming.

CORNUCOPIA. Has immense flowers, white 作 ches across, each appearing to be made up of three distinct flowers. Very fragrant.

YELLOW, GOLDEN QUEEN. Golden Queen new double, triple or quadruple, bright yellow and showy variety.

MIXED.

\section{DAISY, (Bellis)}

This well-known flower has been so greatly improved by cultivation and selection, that now nearly 100 per cent. of blossoms are double. Splendid for early spring and summer flowering when planted in a shady place. Mixed colors.

\section{DEPHINUM (Larkspur)}

The Larkspur is one of the handsomest and most useful of plants, and for large gardens is invaluable. Fine for cutting, They have a large range of color, making a showy ornament in garden or lawn.

ANNUAL MIXED. This includes the Rocket and $\mathrm{Hyacinth}$ varieties, blooming ANNUAL MIXED. the first year from seed.

PERENNIAL MIXED. Very tall-growing, beautiful shades of color.

\section{DIGATALIS (Foxglove)}

Plants grow to the height of 3 or 4 feet and produce dense spikes of brilliantly colored flowers. Colors, white, lavender,,rose. A valuable perennial.

\section{DIANTHUS (Pinks)}

The Dianthus family furnishes the florist with many of his most beautiful flowers including the Carnations, Sweet Williams, Chinese and Japanese Pinks, in all of their varieties. They are easy of culture. Seed may be sown in the ground, but better results may be obtained by starting the plants in the house.

HEDDEWDGII, MIXED. (Japan Pinks.) Unusually large and brilliant.

\section{DOUBIF CHINESE MIXED. The flowers of all a $\mathrm{re}$ very double.}

PLUMARIS MIXED. Fragrant perennials of oldtime gardens.

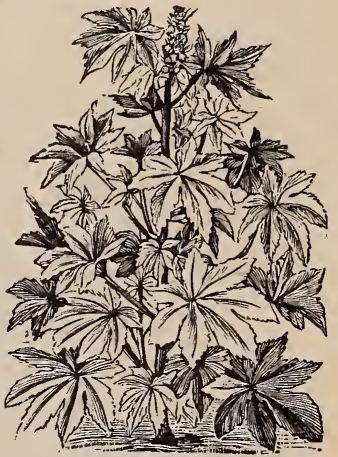

\section{DOLICHOS}

HYACINTH BEAN. A fine climber with abundant clusters of white or which are followed by ornamental seed pods. Tender annual.

Do not fail to include in your order a variety of Dahlias. Nothing. can give you such pleasure in autumn as these improved varietits, Cactus, Pompon, etc. See page 27. 


\section{ECHEVERIA（Hen-and-Chickens)}

These plants will furnish a real surprise, for few people have any idea of the great variety in shape and coloring that can be found among the Echeverias. Try a packet of seed and be both surprised and pleased.

\section{EDELWEISS}

The true and famous Edelweiss of the Alps. The flowers are downy, pure silver white, star shaped. Not too rich soil, and give full exposure to the sun.

\section{ESCHSCHOLTZIA (California Poppy)}

These brilliant flowers belong to the poppy family and are as valuable as the common poppy for ornamentation and are as easily grown. Nothing is handsomer or richer in color than a bed of these in full bloom.

ROSE CARDINAL. Tery deep carmine. A rery beautiful variety of this beautiful strain of flowers.

MANDARIN. Deep orange. A very lovely sort.

\section{EUPHORBIA}

VARIEGATA. " "Snow on the Mountain.") A showy border with foliage veined and margined with white; very attractive.

HETEROPHYLLA. ("Fire on the Mountain.") Ornamental leaves, which take on a deep fiery appearance.

\section{FORGET-ME-NOT}

MYOSOTIS. A favorite, old-fashioned flower, bearing clusters of blue blossoms. It thrives well in the shade or in the open border. Hardy perennial.

\section{FOUR-O'CLOCK}

MARVEL OF PERU. The plants grow large and need space of 3 or 4 feet each way for their best development. The flowers are funnel-shaped, white, red or yellow, or

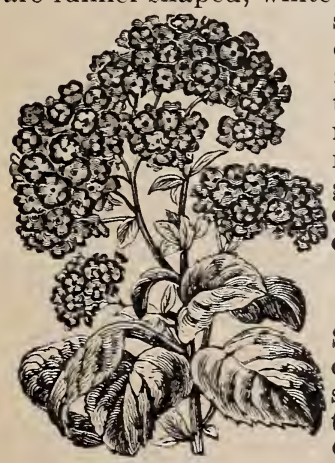

Heliotrope striped with these colors. Ther open about 4 o'clock in the afternoon, and remaining open all night. Very fragrant. The French call it the "Belle of the Night.'

\section{GALLIARDIA}

Showy plants with daisy - like blossoms, flowe ring the first year. The Galliardia is among the brightest ornaments of the garden. Very useful for cutting.

\section{ANNUAL MIXED. \\ PERENNIAL MIXED.}

\section{GODETIA}

Of hardy annuals none are more lovely than these. Of dwarf habit of growth, the flowers are of handsome shape, in the most brilliant and delicate colors and are produced in the nost marvelous profusion. Of easiest culture, a child can grow them.

\section{GOURDS}

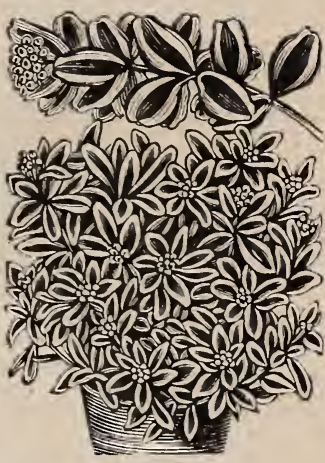

Euphorbia
A tribe of climbers with curiously shaped and colored fruit. Being of rapid growth they are fine for covering old fences, stumps. etc.

DISH CLOTH. A rapid climber haring long DISH CLOTH. green fruit, the inside of which is a fibrous mass, making an excellent bath sponge.

NEST-EGG. The name of this rariety is indicWhite and ative of its appearance, being crack and are not hurt by heat or cold. They make excellent nest-eggs.

\section{MIXED.}

\section{GYPSOPHILIA}

Delicate flowering little plants, covered with a profusion of white and star-shaped blossoms. Well adapted for baskets or edgings. Easily grown.

ELEGANS. ("Angel's Breath.") White and pink ELEGANS. flowers. Hardy annual.

PAIRREULATA. ("Baby's Breath.") Flowers HELIOTROPE

Valued for its fragrance and duration of bloom. Will bloom the first year from seed.

\section{HOLLYHOCK}

For a background there is nothing prettier than the modern Hollyhock, which is much more beautiful than the old-fashioned kind. The flowers are richer colored, larger, and the double varieties are fuller and of much better form.

ALLEGHANY MIXED. The first point of old flower is that it is a perpetual bloomer, and will bloom the first year from seed. The colors are shell pink, rose and red. Very desirable for any garden either large or small.

DOUBLE MIXED.

\section{HUMULUS (Japanese Hop)}

VARIEGATED. An easily-grown hardy annual unsightly obiects or verandas. Self sowing after the first year.

\section{ICE PLANT}

MESEMBRYANTHEMUM. A curious plant for edgings. The stems are succulent and seem to be covered with ice crystals.

\section{IPOMOEA}

MOONFLOWER, NOCTIFLORA. This lovely variety of elimbers can be grown in the greenhouse or open air. Is a generous bloomer beginning early.

LEARI. The blue Moonflower.

\section{KENILWORTH IVY}

LINARIA. A beautiful basket or vase flower plant thriving in a cool, shady place, having small, delicate blossoms in abundance, Water freely. firows rapidly from seed. 


\section{KOCHIA SCOPARIA}

SUMMER CYPRESS. Truly a quick-growree-like shape, and in the foll ing annual, with bright red flowers, giving the plant the appearance of a large ball of fire.

\section{LATHYRUS}

EVERLASTING PEA. Showy, hardy, perways in blossom. Useful for cuttiug.

\section{LOBELIA}

A fine plant for baskets or borders. Dwarf, with graceful foliage and fine flowers.

SPECIOSA. Dark blue. Best for baskets.

CRYSTAL PALACE: (Compacta.) D e e p CRYSTe, dark foliage; the best bedding sort. Beautiful also for borders.

\section{LUPINUS}

Strong annuals, 1 to 3 feet high, with beautiful blue, pink and white flowers. They are of the family of sweet peas, though self-supporting.

\section{DOUBLE.}

SINGLE.

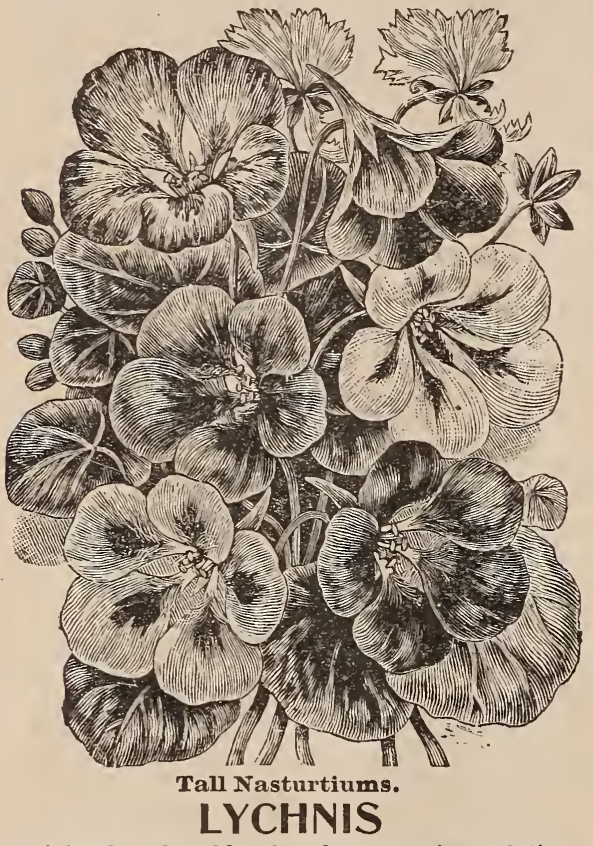

Brilliantly colored border plants, having relationhip with the pinks.

CHALCEDONICA. An old favorite Lychuis sometimes called Rose Campion, Jerusalem Cross and Burning Star.

HAAGEANA. Hybrids of mixed colors from MARIGOLD

No old fashioved garden was complete without this gorgeous flower, and no modern garden can afford to be withoutit

TALI AFRICAN. This variety is not affected in brilliant in color after a frost. The French varietie are more tender.

ORANGE KING Large double flowers, shaded

\section{MAURANDIA}

Graceful climbers for the house or greenhouse. Colors white, rose and purple.

\section{MIGNONETTE}

A well-known hardy annual, producing dense spikes of very fragrant flowers. Seed sown in autumn will bloom early in the spring.

GRANDIFLORA. Large - flowered, fragrant blossoms; if sown at intervals it will bloom until killed by frost.

MATCHET. Dwarf, generous bloomer, very satisfactory.

\section{NICOTIANA}

Highly decorative and desirable annual plants; very sweet scented flowers.

AFFINIS. Bears - sweet smelling large white flowers open morning and evening.

\section{NASTURTIUM}

There are few flowers that compare with the Nasturtiums in the magnificent display of their many and brilliant colored flowers. They are not surpassed in ease of culture and general usefulness. To produce the most flowers they should not be grown in too rich soil.

CLOTH OF GOLD. Very distinct in color foliage of a bright yel-

EMPRESS OF INDIA. Very dark foliage

KING OF TOM THUMBS, Deep scarlet flowers with dark foliage.

REGELIANUM. Blossoms purplish violet, light REGELIANUM. green foliage.

SPOTTED KING. Very handsome.

VESUVIUS. Bright salmon pink, dark leaved.

YELLOW. A brilliant yellow of English origin.

DWARF MIXED.

\section{Tall or Climbing Nasturtiums} COCCINEUM. Bright scarlet.

GOLDEN CLOTH. A beautiful variety, flowers bright scarlet, foliage rolden yellow. Distinct.

KING THEODORE. $\begin{aligned} & \text { Very dark, almost } \\ & \text { black. Dark green }\end{aligned}$ foliage.

MIXTURE of tall varieties. Any variety of Nasturtium 10c per ounce.

\section{POPPIES}

\section{(Papaver.)}

These handsome flowers are single and semi-double, beautiful in color, from pure white to deep crimson, shiny and glossy as silk, having a tissue paper appearance. Very beautiful, grown in masses.

SINGLE MIXED. All colors mixed.

DOUBLE MIXED. All showy varieties.

ICELAND. A hardy perennial blooming the and rellow resembling crushed satin. Very fragrant. Fine for cutting if cut as soon as open.

ORIENTALE. Enormous flowers of deep

ORIENTALE. flashing scarlet with purple shadings at base of petal. A magnificent flower: entirely hardy anywhere.

\section{PYRETHRUM}

\section{(Fever Few.)}

Hardy perennial. Main season of bloom is in June. If old flower stems are removed they will bloom again in autumn.

PARTHENIUM AUREUM. (Golden FeathPARTHENIUM AUREUM. er.) This is fine for edging and makes a beautiful moss-like tuft.

ROSEUM HYBRIDUM. (Double.) Rose high.

\section{POLYANTHUS}

Belongs to the Primula family. Its clusters of Bllow flowers with maroon velvet centers are ver beautiful, and coming in the early spring makes it very desirable for every garden. Mixed colors.

\section{PORTULACCA.}

A favorite annual for edgings, beds, borders, etc. In constant bloom from early summer until autumn. Colors white, pink, crimson, yellow and scarlet. 


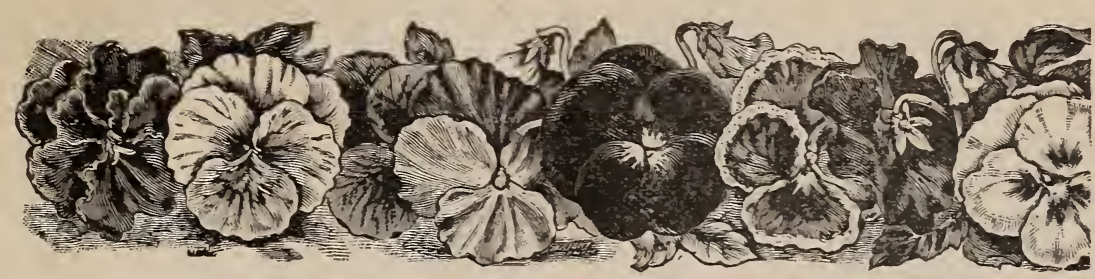

\section{PANSY}

No flower is so much sought after as the Pansy. They are among our finest beauties for summer blooming. Everybody wants Pansies for their garden, so we offer seed of the finest and best-known rarieties.

KING OF THE BLACKS. This is a true black of $\mathbf{a}$ rich velvety texture. Very beautiful.

GOLDEN GEM. Pure relvety gold.

LORD BEACONSFIELD. A beautiful combination of purple, violet, lavender and white. Large flowering.

SNOW QUEEN. A delicate pure white

MAHOGANY. Fine rich brown.

STRIPED AND MOTTLED. An extra large blotched race, of fine colors and form, extra fine.

GIANT MIXTURE. All colors. Pkt. 10c.

\section{PETUNIA}

The Petunia is an early bloomer, and continues a sheet of color until frost. They require good soil and plenty of sunshine.

STRIPED AND BLOTCHED. Small flowers, fine for massing.

HOW ARD'S STAR. A beautiful variety, with a five-pointed star of white in the throat. Good for baskets or rases.

MIXED.

SNOWBALL. A beautiful ruffled variety, pure white. Useful for cutting.

GIANTS OF CALIFORNIA. Large flowers beautifully reined, with yellow shadings in the throat and of many lovely colors. Pkt. 10c.

\section{PHLOX}

No flower in the garden gives more satisfaction in color, form and general beauty than the Phlox. Given rich soil and plenty of room they are unsurpassed by any other flower amoug the annuals. Ex cellent for cutting.

WHITE. Pure white, very beautiful.

PIXK. Beautiful shade of color, with white eve.

SCARLET. Scarlet, with black ere.

YELLOW. Very distinct.

FINE MIXED. All colors mixed.

\section{PRIMULA}

CHINESE PRIMROSE. The Primroses bloom early and generously in cool shaded places. Blossoms are of every shade of color from white to deep crimson, and blue. Some varieties are useful for pot culture, and will bloom profusely in the house in the winter.

\section{LARGE FLOWERIYG FRINGED. Yixed.}

\section{SALPIGLOSSIS}

Very showy bedding plants, with trumpet-shaped flowers, richly colored with purple scarlet, crimson, yellow, and almost black. Grow on very stiff stems, making them desirable for cutting. A great favorite.

\section{SALVIA}

A favorite annual bedding plant. Blossoms in great abundance until frost.

SPLENDENS. The most brilliant flowering plant of the garden with handsome scarlet spikes growing well above the foliage.

\section{SCABIOSA}

MOURNING BRIDE. One of the most desira- ble of border plants

Colors white, lilac, marooll, etc. Very fragrant.

SNOWBALL. White. A beautiful variety and very double. Pure white.

DWARF MIXED. All colors.

\section{SCHIZANTHUS}

This dainty" flower is well named "Butterfly Flower" with its delicate colors and beautiful markings of white, purple and rose, looking like a gay butterfly. The flowers are very fragrant.

\section{SMILAX}

A good climber for the house or greenhouse. Of a dark green color. Very desirable for weddings or funerals, or any place where a dainty decoration is needed.

\section{STOCKS}

These are among the best of our garden annuals when well grown. The flowers are large and double and with their exquisite fragrance they are most desirable for cutting. They have a large range of color in all shades of crimson, rose, lilac and white. Will bloom in ten or twelve weeks after sowing. Grow best in the shade with plenty of water.

CRIMSON. A lovely shade of color, very desiraable.

BRILLIANT ROSE. A beautiful shade of rose. Large and double.

WHITE. A pure white. Very beautiful.

LILAC.

CANARY TELLOW. A delicate clear yellow. DARK BLUE. One of the loveliest of all.

GLANT PER. FECTION. "Cut and Come Again." A pure white rarietr having many side branches. bearing clusters of very fragrant white flowers on long stems.

GOOD

MIXED.

All color

\section{SUNFLOWER}

(HELIANTHUS.)

The Helianthus is easily cultirated, giving good results with little labor. Some of the newer sorts are very ornamental

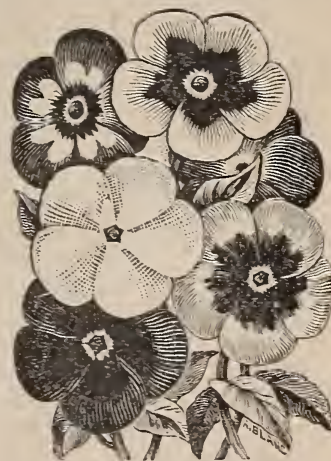

Phlox Drummondi in the flower garden, placed in the background or as screens, or as an absorbent in wet malarial places. The seeds of the common types are used by the farmer for feed.

DOTBLE CRISAYTHEMUY FLOWERED: A tall plant, blooming profusely all summer. Blossoms are large golden yellow, resembling Chrysanthemums.

DOCBIE HIBRID. "Cut and Come Again" These branching single Sunflowers are very much desired for cut flowers; are grown on long stems. and are of beautiful shades of yellow and pure white.

ONE OF THE MOST SATISFACTORT HARDY PLANTS OF THE DAY IS THE PERENNIAL PHLOX. ONCE PLANTED IT REMAIYS AND INCREASES FROMIYAR TO YEAR. SEEPAGE 36 . 


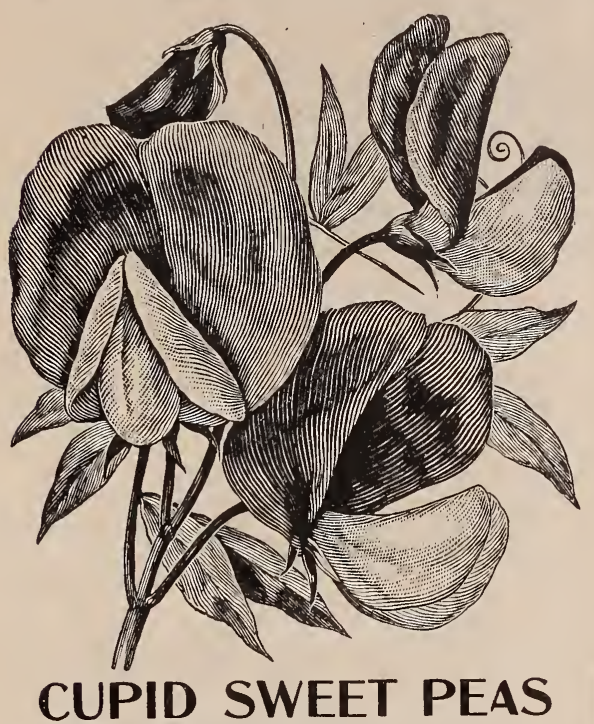

WHITE. Pure white blossoms.

APPLE BLOSSOM. Bright pink, finely shaded.

CAPTAIN OFTHE BLUES. Reddish purple and violet, wings almost deep blue.

FIRE FLY. Glowing scarlet, very bright.

Each of the above Cupid Sweet Peas, per lb. 50c, $1 / 4$ lb. 20c, oz. 10c, pkt. 5c.

\section{SWEETPEAS}

AMERICA. White, striped and veined with bloodred, very choice.

APPLE BLOSSOM. Bright pink and red.

BLACK KNIGHT. Deep maroon. One of the darkest of Sweet Peas.

BLANCHE FERRY. Beautiful clear pink and white.

CAPTAIN OF THE BLUES. Purplish mauve, almost a perfect blue.

COUNTESS. A new, clear lavender.

GOLDEN GATE. Pinkish mauve and lavender.

GRAY FRIAR. Watered purple on white ground. HON. F. BOUVERIE. Standard coral pink; wings lighter.

LADY MARY CURRIE. Salmon orange. One of the brightest.

KATHERINE TRACY. Finest solid pink.

LOTTIE ECKFORD. White, tinted with lavender. NAVY BLUE. The bluest of the blue.

PRINCE OF WALES. Bright rose. Of fine form and substance.

PRIMA DONNA. Soft pink, large size and fine form:

QUEEN VICTORIA. Pale yellow, very large.

SALOPIAN. Blood red. The very best solid red sweet pea.

STELLA MORSE. Cream, with pink shading.

THE BRIDE. One of the best pure whites.

Any of the above by mail, postpaid, 1b. 60c, $1 / 4$ lb. 20c, oz. 10c, pkt, 5c.

CHOICEST MIXED. Made up from the above, 20 separate colors. Per ib., by mail, postpaid, $55 \mathrm{c}, 1 / 4 \mathrm{lb}$. 20c, oz. 10c, pkt. 5c.

GOOD MIXED. Many colors and shades. Per lb., postpaid, $45 \mathrm{c}, 1 / 4 \mathrm{lb}$. $18 \mathrm{c}$, oz. 10c, pkt. $5 \mathrm{c}$.

\section{SWEET SULTAN}

The Sweet Sultan Family have many desirable qualities. They are sweet scented, of many lovely colors, rose, white, lilac, purple and yellow. They have long stems and keep well after cutting. They are the most satisfactory of garden annuals.

MIXED. All colors.

\section{SWEET WILLIAM}

Well-known, hardy perennial plants, old-fashioned favorites greatly improved. They produce masses of brilliant fragrant flowers through a long period. Colors white, crimson, pink, carmine. purple, etc. With eyes and markings. Should be transplanted occasionally.

AURICULA FLOWERED. A beautiful strain with large eves, all colors.

SINGLE MIXED. All colors.

\section{THUNBERGIA}

Trailing plants for basket or vases, blossoms trumpet shaped, of beautiful colors, buff, orange and white.

FINE MIXED. All colors.

\section{VERBENA}

Nothing is more beautiful for beds than Verbenas. In the varieties may be found every color except yellow. They are one of the best annuals.

DEFIANCE. Brilliant scarlet.

WHITE. Large trusses of a pure white.

MAYFLOWER. Is of the same habit as the Arbutus or Mayflower, trailing close to the ground, delicate pink and white with exquisite fragrance.

EXTRA CHOICE. Mixed.

\section{VINCA (Periwinkle.)}

ALBA. A tender perennial plant, blooming the first season. Fine for parlor windows and borders or beds, very pretty. Pure white.

ROSEA. A charming rose pink.

\section{WALLFLOWER}

Wallflowers should be better known. They are easily grown, either in pots or outdoors. Colors, yellow, brownish, purple, etc. Half hardy perennial, bearing long spikes of fragrant flowers.

\section{WILD CUCUMBER}

A very rapid climber, a native of the west, where it grows wild. It has masses of feathery, fragrant, white blossoms followed by ornamental seed pods, very beautiful.

\section{ZINNIA}

Sometimes called "Youth and old Age." Showy plants appearing much like Dahlias when in full bloom. The early frosts do not affect them only to brighten the colors. They come in all the showy colors, yellow, scarlet, de ep red. striped, etc., and both tall and dwarf varieties. Half-hardy annual.

DOUBLE MEXED. DWARF MIXED. LILLIPUT A $r$ T grown on small bushes about 12 or 15 in. high and are literally covered with tiny, very double blossoms, brildouble bloss
liant in color.

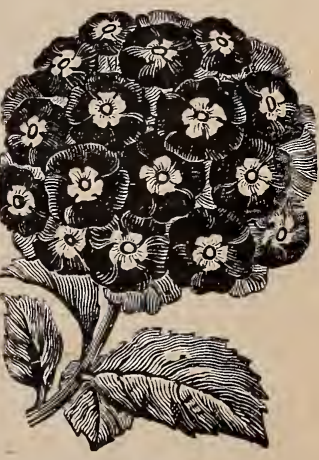

Verbena 


\section{SUMMER FLOWERING BULBS}

\section{GLADIOLUS}

The Gladiolus is one of the most attractive of summer flowers. They are sure to do well with little care, as any soil suits them. Cut flowers will last a week in vases.

FIRST SIZE BULBS, EXTRA FINE, MIXED Each 6c, 4 for 20c, doz. 50c, postpaid.

SECOND SIZE BULBS, ALL BLOO VERS. Each 5c, 4 for 17c, doz. 45c, postpaid.

FIRST SIZE BULBS, GOOD, MIXED. Each $4 \mathrm{c}, 4$ for $15 \mathrm{c}$, doz. $40 \mathrm{c}$, postpaid.

SECOND SIZE BULBS, ALL BLOONERS. Each 3c, 4 for 10, doz. 25c, postpaid.

\section{CALADIUMS}

One of the most effective plants for lawn or greenhouse, growing $5 \mathrm{ft}$. high with handsome leaves often $3 \mathrm{ft}$. long and $20 \mathrm{in.}$ wide if given enough space. Very ornamental and showy.

FIRST SIZE BULBS. $1 \frac{1}{2}$ to $2 \frac{1}{2}$ in. in diameter. Each $10 \mathrm{c}, 3$ for $25 \mathrm{c}$, doz. $85 \mathrm{c}$; postage $5 \mathrm{c}$ extra.

SELECT SIZE BULBS. $2 \frac{1}{2}$ to 3 in. in diameter. Each $12 \mathrm{c}, 3$ for $30 \mathrm{c}$, doz. $\$ 1.10$; postage, $5 \mathrm{c}$ each extra.

\section{GLOXINIAS}

Purely greeuhouse or house plants. Of dwarf habit with large bell-shaped flowers of the most brilliant colors, violet, rose, blue and crimson. One bulb will make a magnificent show. Heat and partial shade are required. Each $15 c, 3$ for $40 \mathrm{c}$, doz. $\$ 1.50$, postpaid.

\section{MADEIRA VINE}

Tuberous rooted climbers with glossy green leaves and fragrant white flowers, of rapid growth, will cover a trellis in a single season. Each $5 \mathrm{c}, 3$ for $10 \mathrm{c}$, doz. $30 \mathrm{c}$.

\section{OXALIS}

Pretty little trailers, good for baskets, pots and vases. Per doz. $10 \mathrm{c}, 3$ doz. $35 \mathrm{c}$.

\section{DAHLIAS}

The Dahlia has always been a favorite for autumn flowering. The flowers are so perfect in shape and have such a large range of color that they will always be popular. The roots are tender and should be protected during winter by placing in a cool cellar and not allowed to freeze. In the spring set out after all danger from frost is over.

COUNTESS OF LONSD́ALE. The most bloomer among the Cactus varieties and one of the very best. The flowers are very large, delicate lemon-pink shading at the edges to a deeper pink.

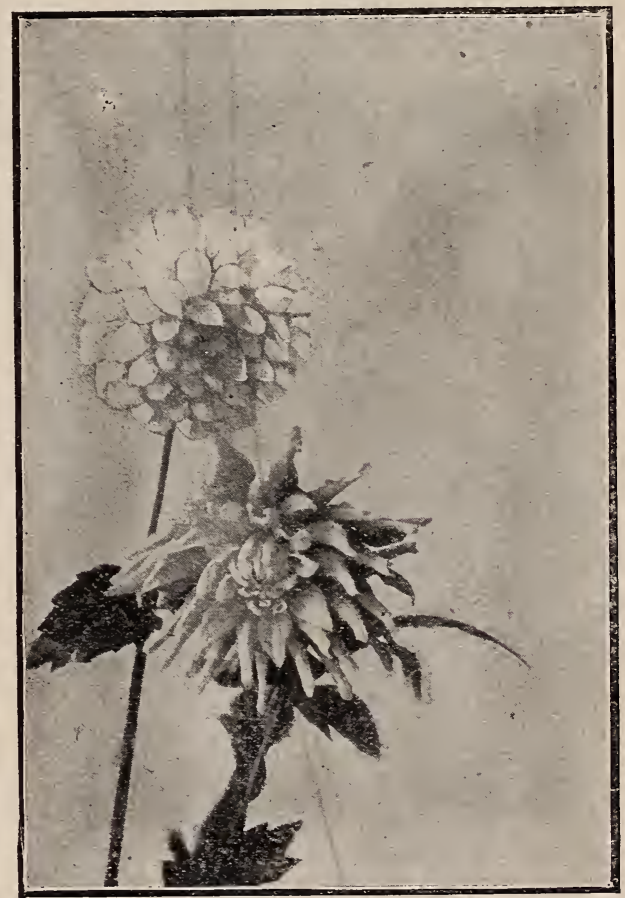

EARL OF PEMBROKE. Bright plum, velvety in the center, petals long, pointed and regularly arranged. FIREBRAND. Pure scarlet, very brilliant, the brightest and most showy of all Cactus Dahlias.

JOHN H. ROACH. Pure yellow, perfect in form, of medium size with pointed petal. The finest yellow Cactus Dahlia to date.

CLIFFORD W. BRUTON. Bright canary yellow, of immense size, perfect form, tall, vigorous grower, MISS THATCHER. Large quilled, golden yellow flowers. Best in cultivation.

LYNDHURST. One of the brightest fiery scarlets, invaluable for cutting, Iong stems.

NYMPHEA. The most delicately beautiful Dahlia ever introduced. resembling the pink water-lily. The PRINCESS BONNIE. A fine large white, splendid for cutting.

ELEGANIE. Soft pink tipped deep pink. Pompon variety.

LA PETITE BARBARA Snow white. One of the Pompons, beautifully quilled.

Any of the above varieties $10 \mathrm{c}$ each, $\$ 1.00$ per doz., postpaid. KRIEMHILDE. Clear rose pink with creamy white center, of the true Cactus form, free blooming, long GRAND DUKE ALEXIS. Extra large, heautifully quilled flowers. clear white color, with pink tinge 


\section{GREENHOUSE AND WINDOW PLANTS}

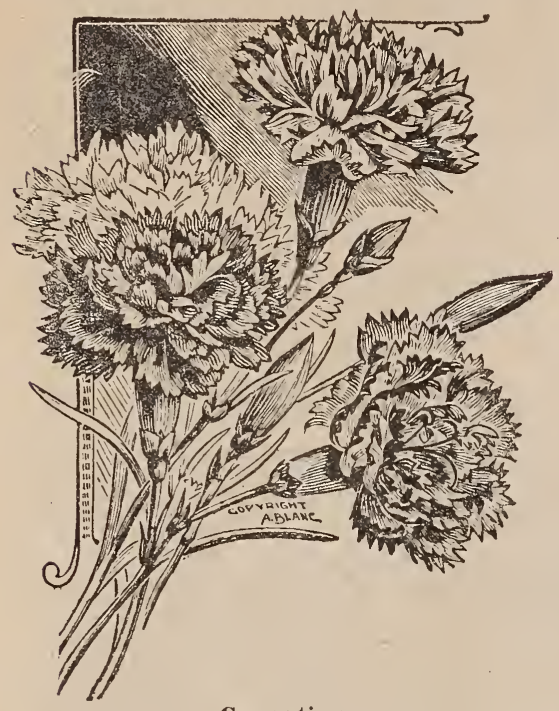

Carnation.

\section{ABUTILON}

Free-growing, decorative shrubs, with bright bell-shaped flowers. Suitable either for house, greenhouse or garden.

BALL OF SNOW. White flowers, plant small and compact, free bloomer.

McKINLEY. A free bloomer all summer, flowers a clear lemon yellow.

SAVITSI. A variety with most beautiful variegated foliage, some of the leaves being a pure white. Thrives well in the open ground, keeping its lovely colors even in the hottest sun. Fine as a border for Cannas and other tall-growing plants. Either of the above 15 cents each.

\section{AGERATUM}

The bright blue of the Ageratum is a great addition to the garden's colors; one of the finest border plants. Also fine for winter blooming in the house.

STELLA GUERNEY. Very beautiful, of dwarf habit, extremely free-blooming. The color is an intense blue, fine for edgings.

LOUIS BONNET. Of dwarf growth, pretty for contrast with Stella Guerney. Pure white flowers. Each 15 cents.

\section{ASPARAGUS}

Beautiful fern-like foliage, fine for decorations. Color bright green, graceful in habit, surpassing all other plants.

PLUMOSUS NANUS Has very graceful foliage, taking the place of Smilax ing cut. An excellent house-plant, 15e each; large plants $25 \mathrm{c}$ by express.

SPRENGERI Especially useful as a pot plant. Always growing the year 'round. 15c each; large plants $25 \mathrm{c}$ by express.

\section{BEGONIAS}

Fine for growing in pots, being perfect in babit with handsome foliage, flowering in profusion all winter, or in beds on the lawn. THURSTONI A fine large plant with handtinted with pink in clusters. 10c each.

RUBRA One of the shrubby kind of Begonias let flowers. 10c each.

M. DE LESSEPS A grand pot plant with white. Exceedingly handsome. Flowers pale pink. 10c each.

VERNON A handsome and free-blooming variety. For the greenhouse they have no equal. They grow readily in pots, bloom early, and are constantly covered with small coral blossoms. Splendid for bedding out in the summer. $10 \mathrm{e}$ each.

\section{CARNATIONS}

Carnations are the most durable of cut flowers. For wearing or decorations they are mequaled, also in coloring, form and fragrance they have no rival. Good for every occasion.

MRS. THOS. LAWSON A beautiful, large measuring $3 \frac{1}{2}$ inches in diameter. GOV. ROOSEVELT The darkest Carnation red with maroon shadings. Vigorous, healthy grower,
WHITE CLOUD Pure white; very lovely.

DAYBREAK More widely known than any other Carnation, and fully merits the grand reputation it has the world over. Color, a delicate flesh pink. Very free-flowering and longstemmed.

NORWAY A pure white. All varieties $15 \mathrm{c}$

GUARDIAN ANGEI Beautiful deep pink long-stemmed. A great favo A constant bloomer

\section{CANNAS}

Cammas are chiefly ornamental; much employed for groups or masses. Brilliant and showy in both flower and foliage.

BURBANK Orehid flowering; large flowers, yellow. Very fine.

ALPHONSE BOUVIER Crimson flowers Tall-growing.

CHAS. HENDERSON Green foliage, crimson flowers, good bedder.

MME CROZY Beautiful shade of red with gold border; green foliage.

QUEEN CHARLOTTE Orange s a arlet, Very beautiful and showy. Green with gold band.

SEC. CHABANNE Brilliant orange with

ALCACE Flowers lemon yellow with green foliage.

FLORENCE VAUGHN. Clear yellow, dotted with brightest red. A perfect bloomer, purple foliage. The best of the new French Cannas.

EGANDALE. Dark foliage, strong flower spikes; color current red. The finest Canna of its color.

SOUVENIR D'ANTOINE CROZY. Green foliage; flowers scarlet crimson, bordered with yellow

AUSTRIA. Large flowers and deep green foliage; color canary yellow, spotted with red.

All of the above varieties 15c each, 2 for $25 \mathrm{c}$, per doz. $\$ 1.25$ 


\section{CHRYSANTHEMUMS}

COL. APPLETON. A beautiful clear yellow, of incurved Japanese type. PHILADELPHIA. Creamy white, rose tipped. 10c each. THE BARD. Large blooms of a clear dark red color. 10c each. MRS. PERRIN. Large incurved, pure satiny pink. 10c each. PINK IVORY A well-known pink sport from Ivory. 10c each. WANAMAKER. Creamy white, large blooms, long stems. 10c each. MAUD DEAN. Beautiful clear pink. 10e each. MODESTO. A rich incurved yellow. 10c each. SUNDERBRUCH. Golden yellow; of the largest size. 10c each. MAJ. BONNAFON. Lemon yellow; a grand flower. 10c each. GEO. W. CHILDS. Deep rich red with orange shadings. 10c each. PINK GIANT. Bright pink; large blooms. 10c each. GLORY OF THE PACIFIC. Fine pink; one of the leaders. 10c each. IroRx. Small, pure white. 10c each.

SILVER WEDDING. Pure glossy white, very broad petals. 10c each. THE BRIDE. Pearly white; large flowers. 10c each.

WM. H. ROBINSON. Clear white. 10c each.

YANARIVA. Immense flowers; delicate blush. 10c each.

\section{POMPOM CHRYSANTHEMUMS}

ANGELIQUE. White; very compact and graceful. $10 \mathrm{c}$ each

MAGNIFICUS. Pure white, of large size and good form. 10c each.

MRS. BATEMAN. Orange brown; one of the best of its color. 10e each.

VIOLA. Deep violet; a very showy flower. 10c each.

ZENOBIA. Bright yellow; fine for sprays. $10 \mathrm{c}$ each.

\section{COLEUS}

Handsome foliage plants for pot culture, but especially fine for bedding out.

DEWEY Deep maroon with a pointed center DEWEY of bright crimson. They will color finely in the hot sun. making the brightest show either out or in, of any Coleus that we know of.

GOLDEN BEDDER One of the sunniest of (he Coleus family: schaffeltii or Dcwey, when bedded out. $10 \mathrm{c}$ each.

VERSCHAFFELTII Best red bedding Col-

\section{ENGLISH IVY}

Sometimes grown as a house plant but hardy for outdoor growing, being generally used for covering walls or for covering graves. True evergreen with dark glossy green leaves. 15c each.

\section{TUBEROSES}

Small waxy white lilies, with extremely fragrant blossoms. Too well-known to need an extended description.

EXCELSIOR DWARF PEARL. Dwarf, double full-flowered spikes; sturdy and strong in habit. Each 7c, 4 for 25c, dozen 60c. Postpaid.

Smaller bulbs, each 5c, 3 for $12 \mathrm{c}$, dozen $40 \mathrm{c}$. All postpaid.

\section{FUCHSIA}

SPECIOSA. Pale red tube and sepals, dark red corrolla. Very beautiful and showy.

GLOIRE de MARCHES STORM KING. A large double variety, white with crimson tube and sepals. 10c each.

\section{GERANIUM}

Plants esteemed both for house culture and bedding. They need no description as they are so well known.

A LPHONSE RICARD. Bright scarlet, large florets of the Bruant type. Dwarf and branching. Equally good for house or greenhouse. 10c each.

s. A. NUTT. Double crimson, very beautiful and a constant bloomer, $10 \mathrm{c}$ each,
JEAN VIAUD. The best of all semi-double pink Geraniums. Stands rain or drouth and is a perfect mass of color all summer. $10 \mathrm{c}$ each.

MRS. E. G. HILL. Bright salmon, perfect in form with light shading at the center., A constant bloomer, 10c each.

MME. CHAS. MOLINE. Showy single variety. Bright salmon pink. Plants compact and branching An excellent variety. 10c each.

LA FAVORITE. Trusses very large and is one of the purest white. 10c each.

MME. SALLEROI. Green and white leaves, some of them being pure white among the green. Very ornamental and good for borders or edging. $10 \mathrm{c}$ each.

MOUNTAIN OF SNOW. Silver and green. Beautifully shaped leaves with silver edge. 10c each.

\section{PELARGONIUMS}

\section{Lady Washington Geranium}

Grand old farorites, but the new varieties are far in advance of the older kinds. They are so well known that they do not need an extended description.

MADAME THIBAUT. White, blotched with rose; immense trusses of large fine flowers

VICTOR. Bright cherry red, white markings at base of each petal; two upper petals heavily spotted with deep maroon. Each 20c, 3 for 50c.

\section{BOSTON FERN}

The most popular of all decorative plants. It is the best among Ferns for the house, and is also beautiful for outdoor decorations in the summer, if partly shaded. They are rapid growers and will thrive in all rooms; gas or furnace heat does not seem to injure them. Beautiful also for hanging baskets. In 2 -in. pots 15 c, 3 -in. pots $25 \mathrm{c}, 4$-in. pots 50 c.

FERN BALL. An interesting and decorative house plant, which flourishes in a window suspended by a cord. Lives upon air and water; requires neither pot nor soil. To start them into growth soak them in water for a short time, and then hang them up in the light. In a short time the ball will be covered with tiny fern leaves, soon covering the ball with their beautiful foliage. $75 \mathrm{c}$ each.

\section{PANSY PLANTS}

Strong transplanted plants from choice seed. By mail 25c dozen, postpaid. Larger plants by express $25 \mathrm{c}$ and $50 \mathrm{c}$ per dozen.

Heliotrope, Impatiens Sultani, Lantana, Lemon Verbena, Petunia, Salvia, 10c each.

\section{VINCA}

Beautiful variegated trailer. Fine for rock work, haskets, etc. 10c each, postpaid 


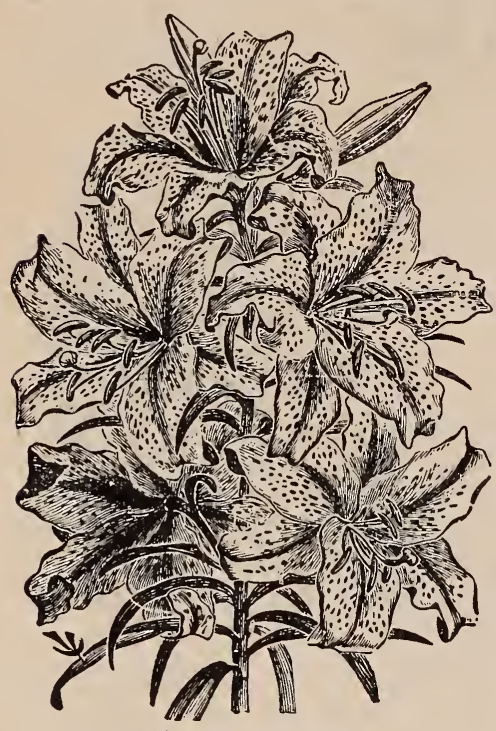

Hardy Lilies

AURATUM, GOLD-BANDED LILY. The best of all hardy lilies. Flowers white, spotted with maroon, with a bright yellow band running through each petal. Very fragrant. First size bulbs, each 20c.

LONGIFLORUM, EASTER LILY. Bears flowers of rare fragrance. White, growing in clusters. Each 25c postpaid.

TIGRINUM, FL. PL. Very large double flowers. Orange red, spotted with black. Each 12c.

TIGRINUM. Flowers Orange red, spotted with black, very showy. Each 12c.

TENUIFULIUM. Flowers dazzling scarlet, with slender graceful stems, the first to bloom. Each 15c.

\section{SPECIOSUM, HARDY JAPAN LILIES}

Once Planted Outdoors, There to Stay.

ALBUM. Large, fragrant, pure white. Each 25c.

RUBRUM. White, spotted with crimson, exceedingly fragrant. Each 25c.

\section{LILY OF THE VALLEY}

Large luxuriant foliage, flowers small, bell-shaped and very fragrant. An old-fashioned garden beauty. Pips, 3 for $10 \mathrm{c}$, doz. 25c. Large clumps $25 \mathrm{c}$ each.

\section{HARDY CLIMBING AND TRAILING VINES}

\section{AMPELOPSIS--BOSTON IVY}

VEITCHII. The leaves of this beautiful climber overlap each other, closely clinging to wood, stone or brick, unpainted or painted, making unsightly places beautiful and picturesque. Each 25c.

QUINQUEFOLIA, (Virginia Creeper.) Used for the same purpose as the Boston Ivy, very strong vines and sturdy growth. Each $20 \mathrm{c}$.

\section{CLEMATIS}

PANICULATA. A vine of very rapid growth. delicious fragrance, color white, one of the best of climbers. Two years old, $25 \mathrm{c}$ each.

HENRYI. Large, single, white, very fragrant. 40c each.
JАСКМАNI. Rich deep velvety purple, blooms with great profusion. $40 \mathrm{c}$ each.

\section{HONEYSUCKLE}

HALLS JAPAN. A strong growing sort, color white changing to yellow, very fragrant. Each $25 \mathrm{c}$. MONTHLY FRAGRANT. Red and yellow, very fragrant. Each $25 \mathrm{c}$.

SCARLET TRUMPET. Bright red trumpetshaped flowers. Each 25c.

\section{WISTERIA}

PURPLE. Rapid-growing climbers suitable for porches and trellises. Flowers purple and grow in long clusters like bunches of grapes. Small plants $25 \mathrm{c}$. Large plants $50 \mathrm{c}$.

\section{Hardy Flowering Shrubs \\ ALTHEA--ROSE OF SHARON \\ CYDONIA JAPONICA}

A free-flowering shrub of easy culture and very desirable on account of blooming in August and September, when scarcely any other shrub is in blossom, flowers resemble a double hollyhock. Colors red, white, deep violet and variegated. $40 \mathrm{c}$ each.

\section{BARBERRY}

PURPLE LEAVED. A beautiful shrub either in its purple foliage or when in fruit. $35 \mathrm{c}$ each.

THUNBERGII JAPANESE. Drooping yellow flowers, deep glossy green foliage. 25c each.

\section{CALYCANTHUS}

SWEET SCENTED. The Calycanthus is one of the most desirable shrubs. The wood is fragraut, foliage rich, flowers of a chocolate color, with a pineapple fragrance. $40 \mathrm{c}$ each.

\section{LILAC}

Almost everyone is familiar with the beautiful Lilacs and their large heads of fragrant blossoms. Desirable for all good gardens,

PURPLE. A very fine lilac. Color purple, large head, fragrant.

WHITE. Pure white, fragrant flowers. $30 \mathrm{c}$ each. FORSYTHIA

Deep glossy green foliage and bright yellow flowers, with drooping habit. $35 \mathrm{c}$ each

\section{TAMARIX--AFRICAN}

Beautiful shrub with small juniper-like leaves. Flowers pink. $50 \mathrm{c}$ each.
JAPAN OUINCE. One of the best shrubs. Large deep scarlet flowers in abundance followed by large fruit. $40 \mathrm{c}$ each.

\section{HYDRANGEA}

PANICULATA GRANDIFLORA. This is a grand plant, very showy and attractive Color pure white changing to pink, remaining on the bush a long time. $25 \mathrm{c}$ and $40 \mathrm{c}$ each.

\section{PRUNUS PISSARDII}

PURPLE LEAVED PLUM. The best purpleleaved shrub, flowers small, white, single, covering the tree. $40 \mathrm{c}$ each.

\section{PHILADELPHUS}

MOCK ORANGE, Syringa. A well-known shrub, hardy, vigorous, and beautiful in flower and foliage. $40 \mathrm{c}$ each.

\section{SAMBUCUS--ELDER}

AUREA. Golden yellow foliage. $35 \mathrm{c}$ each.

\section{VIBURNUM--SNOWBALL}

COMMON. A much-admired shrub with balls of white flowers. Young plants $40 \mathrm{c}$ each.

\section{SPIREA}

VAN HOUTTEII. One of the most beautiful of all the garden shrubs, entirely hardy, immense bloomer, pure white flowers. This is the plant for the people. $40 \mathrm{c}$ each.

All of the above are 3-year-old plants and must go by EXPRESS; we have no small plants to offer. 


\section{ROSES}

HARDY GARDEN ROSES

The Roses listed below are perfectly hardy and will stand severe cold if planted in well-drained soil, and lightly mulched during the winter. Do not forget to prune them severely in the spring.

AMERICAN BEAUTY The largest rose among the hardy varieties; color, deep rose. In its large size, beautiful color, long stem and continuous bloom, no other rose approaches it in usefulness and beauty.

BARON DE BONSTETTIN Dark velvety red almost black, large double flowers, of beautiful form. Very fragrant.

GEN. WASHINGTON Flowers of beautiful scarlet, sometimes deepening to crimson.

KAISERIN AUGUSTA VICTORIA Snow white. Blooms in profusion all summer. Should be protected in the winter. One of the best of the tea roses.

MARGARET DICKSON White with petals tinted in the center; good form, handsome foliage. Best of the Hybrids.

MME. CHAS. WOOD A true perpetual bloomer, with extra large double and very fragrant flowers. Color, bright scarlet shaded with maroon.

PAUL NEYRON Deep rose color; largest of all; perfect in form, and is considered the finest pink rose.

PERSIAN YELLOW The flowers are semi-double; golden yellow color; perfectly hardy. COQUETTE DES ALPS Snow white, rose-shaded center.

GEN. JACQUEMINOT Too well known to need a long description. A rich crimson color, with darker shadings.

LA FRANCE This is a fine plant for out of doors or in the greenhouse. The flowers are light silvery pink with delicious fragrance.

MRS. JOHN LAING A free-blooming Hybrid, perpetual, with flowers of a soft delicate pink with satin cast.

PRINCE CAMILLE DE ROHAN Velvety crimson-shaded scarlet. One of the darkest roses. Any of the above $35 \mathrm{c}$ each. Per doz. $\$ 3.00$, by express.

SOLEIL D' OR Here is a double rose hardy enough to stand the winters of the Northern states. A beautiful yellow with tints of copper in the center. Very lovely and desirable. $50 \mathrm{c}$ each.

GRUSS AND TEPLITZ The reddest of all red roses. Velvety in texture, free, stronggrowing and profuse bloomer. Very fragrant. 40c each.

\section{CLIMBING ROSES}

CRIMSON RAMBLER The most wonderful of all the new roses. It has no equal in habit of growth and foliage, and produces in great abundance clusters of the brightest crimson semidouble roses.

YELLOW RAMBLER Clear yellow flowers, vigorous climber.

DOROTHY PERKINS A new Rambler rose, beautiful clear shell pink. Large clusters. CLOTHILDE SOUPERT (Climbing) Ivory white, with silvery rose center. Great bloomer. BALTIMORE BELLE Pale blush color. Flowers in clusters. A rapid climber.

PRAIRIE QUEEN An old standard variety; very popular. Color, bright rosy red, flowers large, compact and round.

Prices, 35c each. Per doz. $\$ 3.00$, by express.

\section{EVER-BLOOMING ROSES}

CLOTHILDE SOUPERT (Polyanthus Tea) Blush nink. One of the finest roses for garden or greenhouse. BRIDESMAID A dark rich pink, most desirable sort for garden or winter forcing. Tea scented with beautiful buds for cutting.

BON SILENE Noted for the beauty of its buds. Carmine rose shaded with salmon.

METEOR A rich dark crimson. Very double. In bloom all summer.

MME. DE WATTEVII.LE Color white with salmon tints.

PERLE DES JARDINS Canary vellow; with stiff stems. Very free flowering. Tea srented.

SOUVENIR DE WOOTTEN A beautiful Hybrid tea rose. Color brimt magenta red. One of the most fragrant in the whole list. Hardy, but valued for a winter-flowering rose.

BRIDE The most popular white rose for winter-floweriug. Nothing excels it in midwinter.

LA FRANCE Pink, with a satiny sheen over its petals. The most perfect type of a cut rose. Flower large, with the well-known fragrance.

$10 \mathrm{c}$ each. Per doz. $\$ 1.00$. 


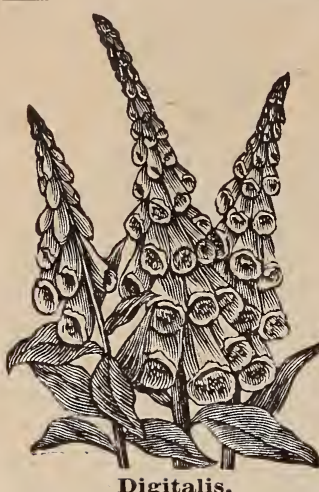

Digitalis.

\section{HARDY PE PERENNIAL PL PLANTS}

DIACENTRA SPECTABILIS (Bleeding-Heart). Flowers heart-shaped, rose-colored. Early and abundant bloomer. Very beautiful. 25c each.

CANTERBURY BELLS. An old-fashioned favorite. Bears single and double flowers of great beauty; colors purple, white, rose and other shades. 15c each.

DIGATALIS (Foxglove). These are very satisfactory plants as they give such a wealth of bioom. Thimble-shaped flowers in various colors. $15 \mathrm{c} \mathrm{each}$.

SHASTA DAISY. Perfectly hardy: blooms for several months; flowers broad-petaled and of purest white. 30c each. Small plants $10 \mathrm{c}$ each.

DELPHINUM (Larkspur). Bushy plants much esteemed for cutting. Colors, all shades of blue to nearly white. 15c each by express.

IRIS GERMANICA. This is a broad-leaved variety with many shades of white, blue, rose and yellow flowers. Thrives best near water. Early springflowering plant. Each, 15c; doz., $\$ 1.25$.

IRIS KAEMPFERI. Leaves of the Japanese Iris are narrow, distinct from all others of this genus, producing the most gorgeous flowers known in red, white, rose, blue, crimson and blotched. Grow best near water. Each, 15c; doz., \$1.25.

HOLLYHOCKS. These flowers are gaining in favor every year as the improved varieties are better known. They are as handsome in form as a Camellia Colors, double white, salmon, yellow, crimson and pink. Mixed colors, only $15 \mathrm{c}$.

GAILLARDIA GRANDIFLORA. One mass of bloom from June till autumn. 15c each.

MYOSOTIS, (Forget-me-not.) A very delicate and dainty plant. Early bloomer. Pale blue flowers, covering the plant with lovely color. 10c each.

PEONIES. This hardy, old-fashioned flower has been so improved that we have many shades of color from the purest white to the deepest crimson. Once planted they will last a lifetime. Clump 50c; divided, $15 \mathrm{c}$.

Double Crimson.

Double White.

Double Pink.

PANSY. The Pansy is the best shipping plant we have. Thrifty plants will stand a long journey. The colors are too well known to need description. International and other fine strains, $25 \mathrm{c}$ to $50 \mathrm{c}$ per doz.
PHLOX. The Phlox is an early-flowering perennial, blooming freely from July until late in the autumn. Easily grown. Each, 15c; doz., \$1.25.

Esclarmonde. Purplish white, deep rosecolored eye.

- Eclaireur, Dark crimson, very beautiful. One of the choicest varieties.

- Amor. Clear pink; light center; dwarf growth. - Coquelicot. The brightest and the most showy of the Phlox. Color, orange-scarlet with crimson eye. Continues in bloom a long time.

-Jeanne D'Arc. Absolutely snow-white; late bloomer. Begins to bloom about the 4th of July.

- Cross of Honor. Magenta, with white margin in the form of a Maltese Cross. Very distinct and beautiful.

- Cameron. Large, perfect flowers; flesh pink, with compact flower-heads.

HARDY GARDEN PINKS. Once planted the garden ninks are there to stay, and continue to increase as the years go by. Their delicate colors, graceful habit, and, above all, the delightful clove scent make them a general favorite. Red, white, pink and variegated are the chief colors. $10 \mathrm{c}$.

RUDBECKIA. Golden Glow. This is one of the sunniest of hardy plants; beautiful golden yellow; long stems. Excellent for cutting. 10c.
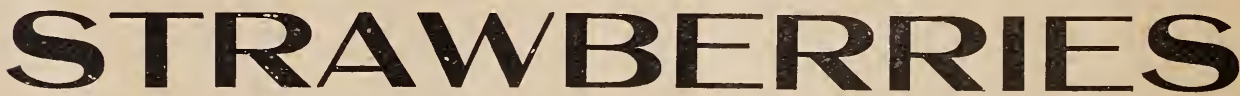

HAVERLAND. This variety has given satisfaction over a large range of country. Some varieties do well in certain localities and fail in others, but the Haverland seems to succeed every where. The vines are vigorous and deep-rooted. making plenty of runners. The fruit is somewhat long in shape, bright red in color, without any ill-shaped berries, and parting easily from the calyx when being prepared for the table. A splendid variety for home use or near-by market, but not quite so solid for shipping as the Warfield. The most productive berry we have ever grown. This variety is a Pistilate, or imperfect flowering sort, and should have every third or fourth row planted with Lovett.

Price, by mail, doz. 25c; 100 for $\$ 1$; by express, 10060 c; $1,000 \$ 4$

WA RFIELD. There is no berry grown that equals the $W$ arfield for canning. The color is so dark that this variety can easily be told from any other after they are canned. It is also abundantly productive and a good shipper. It produces so many runners that the bed will become matted and the berries small, but on good ground and by taking care to keep most of the runners off this sort will produce abundant crops of large berries that will delight everyone.

Price, by mail, doz. 25c; 100 for 80 c; by express, 100 for 50 c, 1,000 for $\$ 3$.

LOVETT. Early, productive and of the finest shape and color. A vigorous variety and a good fertilizer for Haviland or Warfield: Price, by mail, doz. 25c; 100 for $\$ 1$; by express, 100 for 60 c; $1,000 \$ 4$.

GLEN MARY. Large and handsome, of finest flavor; vigorous and productive. Many growers consider this the most profitable of all strawberries. This is also a good fertilizer for the imperfectly flowered sorts.

Price, by mail, doz. 25c; 100 for $80 c$; by express, 100 60c; 1,000\$4.

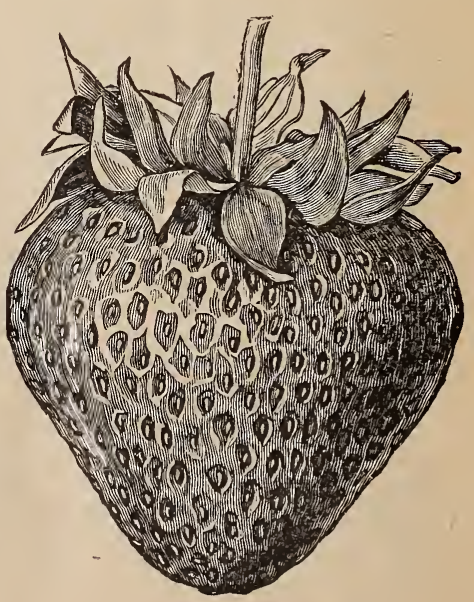




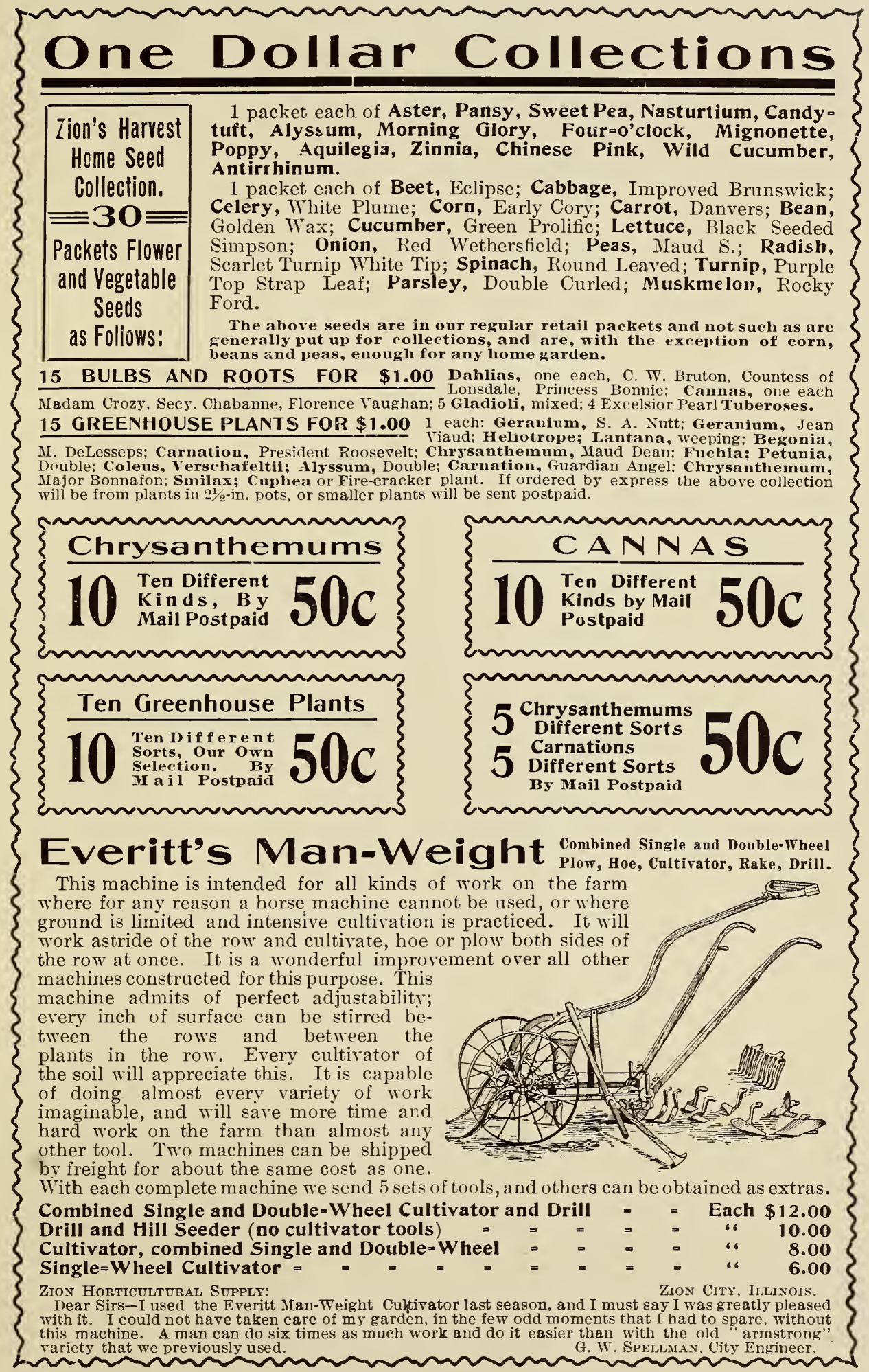




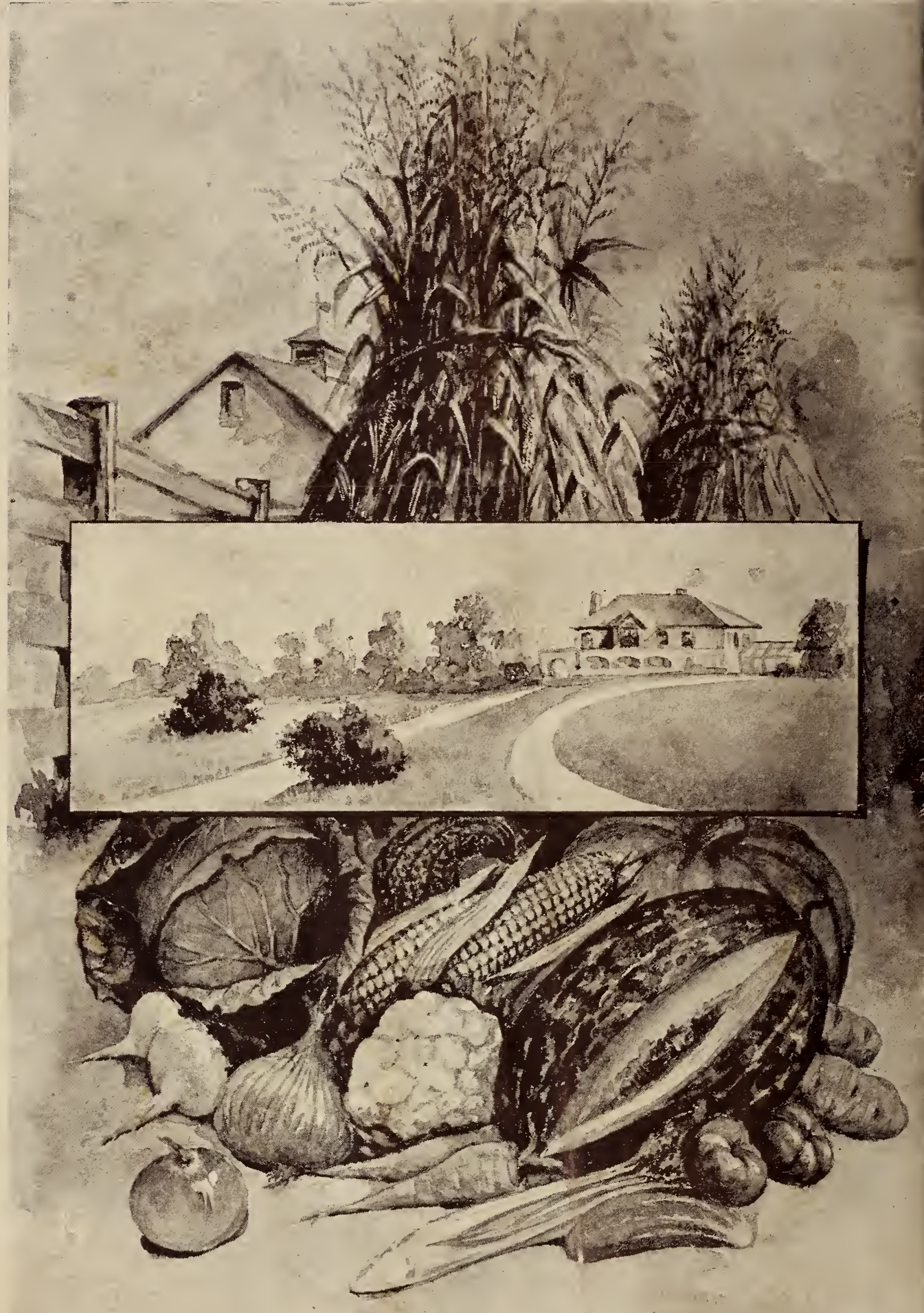

